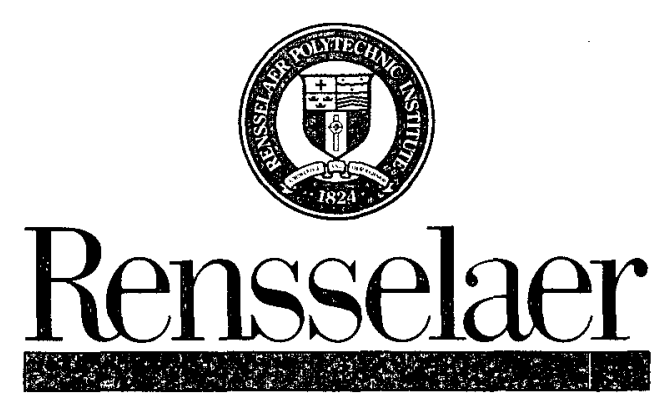

School of Science

Department of Chemistry

April 18, 2001

U.S. Department of Energy

Office of Scientific and Technical Information

P.O. Box 62

Oak Ridge TN, 37831

Dear Sirs:

Enclosed are three copies of my DOE Final Technical Report, "Metal CarbonylHydrosilane Reactions and Hydrosilation Catalysis; (DE-FG02-95-ER14542). Also enclosed are three copies of DOE Form 241.1. I have verified that my Form SF 269A, Financial Status Report, already is at your Chicago Office (contact person: Debra Perez, procurement technician for the Acquisition and Assistance Group).

Sincerely,

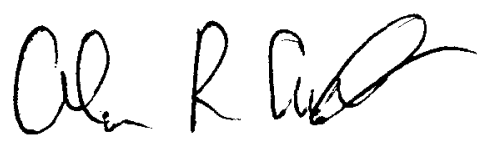

Alan R. Cutler

Professor of Chemistry

(518)276-8447 


\section{DISCLAIMER}

This report was prepared as an account of work sponsored by an agency of the United States Government. Neither the United States Government nor any agency thereof, nor any of their employees, makes any warranty, express or implied, or assumes any legal liability or responsibility for the accuracy, completeness, or usefulness of any information, apparatus, product, or process disclosed, or represents that its use would not infringe privately owned rights. Reference herein to any specific commercial product, process, or service by trade name, trademark, manufacturer, or otherwise does not necessarily constitute or imply its endorsement, recommendation, or favoring by the United States Government or any agency thereof. The views and opinions of authors expressed herein do not necessarily state or reflect those of the United States Government or any agency thereof. 


\section{DISCLAIMER}

Portions of this document may be illegible in electronic image products. Images are produced from the best available original document. 
CURRENT AND PENDING SUPPORT FOR: AIAN R. CUTIER

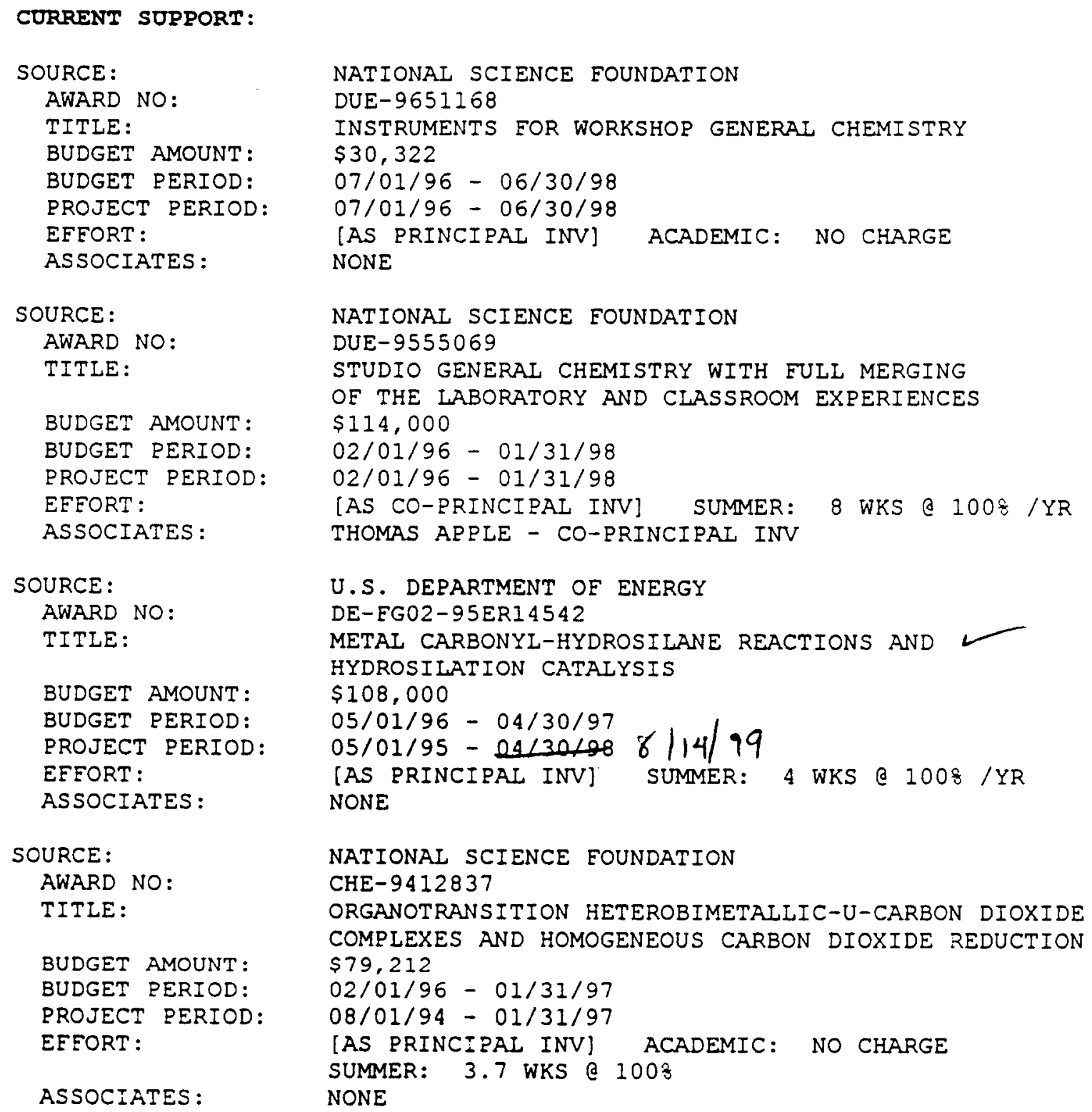

PENDING PROPOSALS: NONE

NOTE:

AMOUNTS SHOWN REPRESENT SPONSOR EUNDING ONIY AND DO NOT INCLUDE COST SHARING. 


\title{
Metal Carbonyl-Hydrosilane Reactions and Hydrosilation Catalysis
}

\author{
Final Report \\ for Period 5/1/95 - 8/14/99 \\ Principal Investigator \\ Alan R. Cutler \\ Professor of Chemistry \\ Rensselaer Polytechnic Institute \\ Troy, New York 12180-3590
}

April 14, 2001

Prepared for

The U.S. Department of Energy

Agreement No. DE-FG02-95ER 14542

Staff Contact Person

Dr. Dennis W. Bennet, Office of Basic Energy Sciences, Chemical Sciences Program 


\section{PROJECT SUMMARY}

Manganese carbonyl complexes serve as hydrosilation precatalysts for selectively transforming a carbonyl group into a siloxy methylene or a fully reduced methylene group. Substrates of interest include (1) aldehydes, ketones, carboxylic acids, silyl esters, and esters, and (2) their organometallic acyl counterparts. Three relevant catalytic reactions (illustrated for carboxylic acids) include,

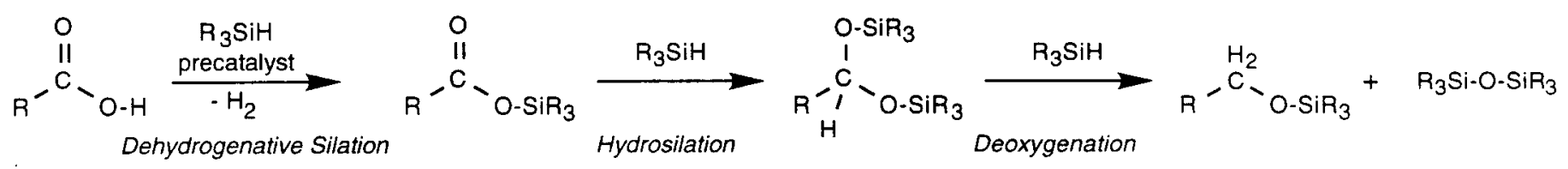

Two types of manganese precatalysts have been reported: (a) alkyl and acyl complexes $(\mathrm{L})(\mathrm{CO})_{4} \mathrm{MnR}\left[\mathrm{L}=\mathrm{CO}, \mathrm{PPh}_{3} ; \mathrm{R}=\mathrm{COCH}_{3}, \mathrm{COPh}, \mathrm{CH}_{3}\right]$ and $(\mathrm{b})$ halides $(\mathrm{CO})_{5} \mathrm{MnX}$ and $\left[(\mathrm{CO})_{4} \mathrm{MnX}\right]_{2}(\mathrm{X}$ $=\mathrm{Br}, \mathrm{l})$. The former promote hydrosilation and deoxygenation catalysis; the latter promote dehydrogenative silation of alcohols and carboxylic acids as well as hydrosilation and deoxygenation of some metallocarboxylic acid derivatives. In every case studied, these $\mathrm{Mn}$ precatalysts are far more reactive or selective than traditional $R h(I)$ precatalysts.

The reaction chemistry of the above and other $\mathrm{Mn}$ alkyl complexes with hydrosilanes was studied in order to probe catalysis mechanism(s). Thus, $\mathrm{Mn}(\mathrm{CO})_{5}$ methyl, benzyl, acetyl, and benzoyl (4 psubstituents) complexes reacted with hydrosilanes by four different mechanisms, which were established. A noteworthy development was that the methyl and benzoyl complexes gave moderate yields of a new $\left(\eta^{2}-\mathrm{Si}-\mathrm{H}\right)$ silane adduct $(\mathrm{CO})_{4} \mathrm{Mn}\left(\mathrm{SiMe}_{2} \mathrm{Ph}\right)\left(\mathrm{H}-\mathrm{SiMe}{ }_{2} \mathrm{Ph}\right)$, which is stable in the presence of excess silane. This silane adduct promotes all three catalytic reactions; its extraordinary activity and potential selectivity are under study. Specific catalysis problems that have been addressed include:

- Catalytic hydrosilation-then-deoxygenation of ketones and organometallic acyls. Mn and Rh(I) precatalysts and $\mathrm{PhSiH}_{3}$ completely reduce iron acyls $\mathrm{Cp}(\mathrm{CO})(\mathrm{L}) \mathrm{FeC}(\mathrm{O}) \mathrm{R}^{\prime}$ to their alkyl derivatives, $\mathrm{Cp}(\mathrm{CO})(\mathrm{L}) \mathrm{FeCH}_{2} \mathrm{R}^{\prime}$. Our $\mathrm{Mn}$ precatalysts very efficiently promote the hydrosilation of ketones.

$$
\mathrm{YC}(=\mathrm{O}) \mathrm{R}^{\prime}+2 \mathrm{R}_{3} \mathrm{SiH} \rightarrow \mathrm{YCH}\left(\mathrm{OSiR}_{3}\right) \mathrm{R}^{\prime} \rightarrow \mathrm{YCH}_{2} \mathrm{R}^{\prime}+\left(\mathrm{R}_{3} \mathrm{Si}\right)_{2} \mathrm{O} \quad\left[\mathrm{Y}=\text { alkyl, Fp, } \mathrm{Mn}(\mathrm{CO})_{5}\right]
$$

- The reactivity/selectivity of $\mathrm{Mn}$ precatalysts and silanes for the catalytic hydrosilation-thendeoxygenation of esters. Deoxygenation of the silyl acetal intermedates and their partitioning between ether and silyl ether deoxygenation products depends upon the choice of silane and precatalyst.

$$
\mathrm{YC}(=\mathrm{O}) \mathrm{OR}^{\prime} \rightarrow \mathrm{YCH}\left(\mathrm{OSiR}_{3}\right) \mathrm{OR}^{\prime} \rightarrow \mathrm{YCH}_{2} \mathrm{OR}^{\prime} \text { and } \mathrm{YCH}_{2} \mathrm{OSiR}_{3}+\mathrm{R}^{\prime} \mathrm{OSiR} 3 \quad[\mathrm{Y}=\mathrm{H} \text {, alkyl, aryl] }
$$

- Catalytic reactions of hydrosilanes with carboxylic acids and silyl carboxylates. Dehydrogenative silation-hydrosilation-deoxygenation of the carboxylic acids gave isolable silyl esters, disilylacetals, and silyl ethers. The catalytic formate - hydrosilane chemistry pertains to $\mathrm{CO}_{2}$ fixation, although more work on the pyrolysis of the disilylacetals is in progress.

$$
\mathrm{HC}(=\mathrm{O}) \mathrm{OH}+3 \mathrm{R}_{3} \mathrm{SiH} \rightarrow \mathrm{CH}_{2}\left(\mathrm{OSiR}_{3}\right)_{2} \rightarrow \mathrm{CH}_{3} \mathrm{OSiR}_{3}+\left(\mathrm{R}_{3} \mathrm{Si}\right)_{2} \mathrm{O}+\mathrm{H}_{2}
$$

- Catalytic Reactions of Hydrosilanes with Metallocarboxylic Acid Derivatives. (CO $)_{5} \mathrm{Mnl}$ catalyzes the hydrosilation-deoxygenation of $\mathrm{Cp}^{*}(\mathrm{CO})(\mathrm{NO}) \mathrm{ReCO}_{2} \mathrm{R}^{\prime}\left[\mathrm{R}^{\prime}=\mathrm{H}\right.$ and $\mathrm{SiR}_{3}$ ], thus providing support for our metallocarboxylic acid pathway for $\mathrm{CO} / \mathrm{CO}_{2}$ fixation.

$$
\mathrm{Cp}^{\star}(\mathrm{CO})(\mathrm{NO}) \mathrm{ReCO}_{2} \mathrm{H}+3-4 \mathrm{R}_{3} \mathrm{SiH} /(\mathrm{CO})_{5} \mathrm{Mnl} \rightarrow \mathrm{Re}^{\star} \mathrm{CH}_{2} \mathrm{OSiMe}_{2} \mathrm{Ph} \rightarrow \mathrm{Re}^{\star} \mathrm{CH}_{3}
$$




\section{A. Prologue}

\section{PREVIOUS · RESULTS}

Our interest in the reactivity of hydrosilanes towards organometallic alkyl/acyl complexes especially the reduction of acyl ligands - is an extension of our previous studies on generating and extending $C_{1}$ and $C_{2}$ ligands using (ligated) CO. ${ }^{1}$ This chemistry entailed sequential carbonylation and reduction steps, with acyl ligand hydrogenation an obvious choice for the latter. These hydrogenation reactions instead typically release aldehydes or the corresponding alcohols. ${ }^{2}$ Indeed, virtually all of the synthesis and CO fixation modeling studies of the 1970's relied on using borane, borohydride, or metal hydride reagents for reducing acyl ligands or their activated alkoxycarbene derivatives. 1,3

Catalytic hydrosilation of acyl complexes became an alternative approach for reducing acyl ligands. Catalytic hydrosilation of organic aldehydes and ketones to alkoxysilanes had been well established as an easy and dependable synthetic procedure, ${ }^{4}$ whereas the analogous catalytic hydrogenation of ketones to alcohols requires more effort in choice of catalyst and reaction conditions. 5

The relative ease of hydrosilation vs. hydrogenation of a ketone is consistent with the results of thermochemical calculations using bond dissociation enthalpies (BDE's). ${ }^{6}$ Surprisingly, it is not the $\mathrm{Si}-\mathrm{O}$ bond strength alone that favors the hydrosilation over the hydrogenation of a ketone. The relative weakness of the Si-H bond versus the $\mathrm{H}-\mathrm{H}$ (by $11 \mathrm{kcal} / \mathrm{mol}$ ) represents a more significant contribution to the $\Delta \mathrm{H}^{\circ}$ rxn than does the strength of the Si-O versus the $\mathrm{H}-\mathrm{O}$ bond (by $3 \mathrm{kcal} / \mathrm{mol}$ ).

\begin{tabular}{|c|c|c|c|c|c|c|c|}
\hline $\mathrm{H}_{2}$ & $+\mathrm{R}_{2}{ }_{2} \mathrm{C}=\mathrm{O}$ & & $\rightarrow$ & \multicolumn{2}{|c|}{$\mathrm{R}_{2}^{\prime} \mathrm{CH}-\mathrm{O}-\mathrm{H}$} & \multirow{2}{*}{$\Delta H^{\circ}{ }_{r \times n}=-13$} & kcal \\
\hline $\mathrm{H}-\mathrm{H}, 104$ & $C=O$ ( $\pi$-bond $)$ & 93 & & $\mathrm{C}-\mathrm{H}, 99$ & $\mathrm{O}-\mathrm{H}, 111$ & & $\mathrm{~mol}$ \\
\hline $\mathrm{Me}_{3} \mathrm{Si}-\mathrm{H}$ & $\mathrm{R}_{2}{ }_{2} \mathrm{C}=\mathrm{O}$ & & $\rightarrow$ & $\mathrm{R}_{2} \mathrm{C}$ & $\mathrm{iMe}_{3}$ & $\Delta H^{\circ}{ }_{r \times n}=-27$ & \\
\hline $\mathrm{Si}-\mathrm{H}, 93$ & $\mathrm{C}=\mathrm{O}(\pi$-bond $)$ & 93 & & C-H, 99 & O-Si, 114 & & \\
\hline
\end{tabular}

When we started our studies, very little was known about the reactions of labile metal acyl complexes with silanes:7,8 the expectation was that silane $\mathrm{Si}-\mathrm{H}$ would add to the metal and eliminate aldehyde as the kinetic product. ${ }^{9}$ Alternative $\alpha$-siloxyalkyl products $L_{x} M C H\left(O S_{i R}\right) R^{\prime}$ were unknown.

Cobalt $\alpha$-siloxyalkyls $(\mathrm{CO})_{x} \mathrm{CoCH}\left(\mathrm{OSiR}_{3}\right) \mathrm{R}^{\prime}$ had been postulated, however, in the seminal studies by Murai and co-workers ${ }^{10}$ as intermediates during the $\mathrm{Co}_{2}(\mathrm{CO})_{8}$-catalyzed silylformylation of alkenes (with $\mathrm{R}_{3} \mathrm{SiH}$ and $\mathrm{CO}$ ). These $\alpha$-siloxyalkyl precursors to the organic products presumably originate via the interaction of in situ-generated $(\mathrm{CO})_{4} \mathrm{CoSiR}_{3}$ with aldehyde; $10 \mathrm{~b}, \mathrm{c}$ the aldehyde in turn derived from a cobalt acyl that came from alkene, $\mathrm{CO}$, and $(\mathrm{CO})_{4} \mathrm{CoH}$. The incorporation of aldehyde into the cobalt silyl has been modeled under non-catalytic conditions in studies by Gladysz and co-workers ${ }^{11}$ using $(\mathrm{CO})_{5} \mathrm{MnSiMe}_{3}$, but again no information was forthcoming on the hydrosilation of metal acyl complexes.

A landmark paper by Markó and co-workers ${ }^{12}$ established two important points. First, the labile $(\mathrm{CO})_{4} \mathrm{CoC}(\mathrm{O}) \mathrm{CHMe}_{2}$ adds $\mathrm{Et}_{3} \mathrm{SiH}$ and generates a transient $(\mathrm{CO})_{4} \mathrm{CoCH}\left(\mathrm{OSiEt}_{3}\right) \mathrm{CHMe}_{2}$, which in the presence of excess silane degrades to the detected products, $\mathrm{Me}_{2} \mathrm{CHCH}_{2} \mathrm{OSiEt}_{3}$ and $\mathrm{Me}_{2} \mathrm{C}=\mathrm{CHOSiEt}_{3}$. Second, $(\mathrm{CO})_{4} \mathrm{CoSiMe}_{3}$ readily incorporates an aldehyde $\mathrm{Me}_{2} \mathrm{CHCHO}$ as a similar $\alpha$-siloxy-isobutyl complex that likewise degrades to analogous organic products. In this and previous studies, all 
mechanistic deduction rested solely on the identification of the organic products.

Our early studies established four points. ${ }^{13}$ (1) We demonstrated the first examples of catalytic hydrosilation of non-labile orgnometallic acyl compounds. Rhodium(I) complexes catalyze the hydrosilation of $\mathrm{Fp}$ acyl compounds; 14 the resulting products were the first $\alpha$-siloxyalkyl complexes to be isolated and fully characterized. (2) The labile manganese acetyl, $(\mathrm{CO})_{5} \mathrm{MnC}(\mathrm{O}) \mathrm{CH}_{3}(1)$, in contrast, readily adds silanes in the absence of added catalyst, and a dozen of the resulting $\alpha$-siloxyalkyl products were characterized. ${ }^{15}$ (3) Unexpectedly, 1 serves as an extraordinarily active precatalyst for the hydrosilation of $\mathrm{FpCOCH}_{3} .{ }^{16}$ For example, $<5 \% 1$ promotes the hydrosilation of $\mathrm{FpCOCH}_{3}$ with $2^{\circ}$ silanes (e.g., $\mathrm{Ph}_{2} \mathrm{SiH}_{2}$ ) as well as with the less reactive ${ }^{17} 3^{\circ}$ silanes (e.g., $\mathrm{PhMe} 2 \mathrm{SiH}$ ),
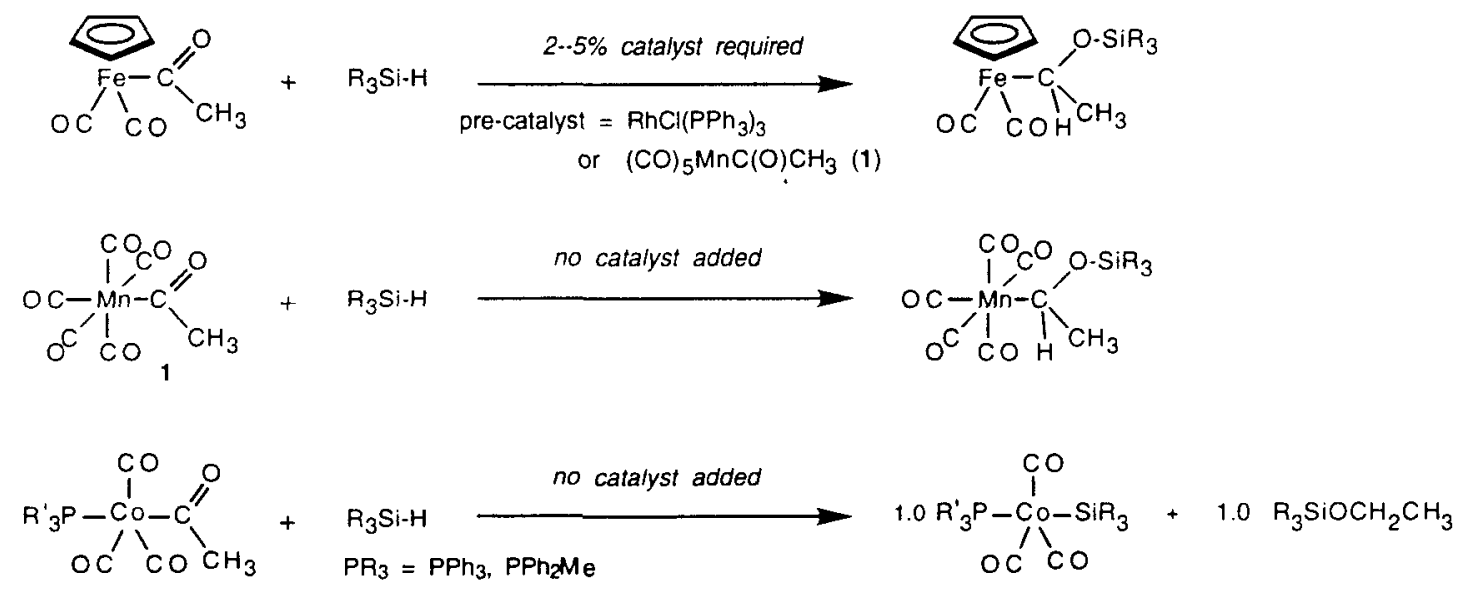

whereas the $R h(1)$ precatalysts only function with the former. (4) Organotransition metal acetyl complexes, in our experience, undergo diverse reactions with silanes. ${ }^{13}$ In addition to the above catalytic and "apparently non-catalytic" hydrosilation of metal acyls, many metal acetyl complexes add 2 equiv. of silane and release the organic products, $\mathrm{CH}_{3} \mathrm{CH}_{2} \mathrm{OSiR} 3$ and $\mathrm{CH}_{2}=\mathrm{CHOSiR}_{3},{ }^{10,11 a}, 12,18$

Results of our study of the above cobalt acetyl compounds ${ }^{19}$ were consistent with an intramolecular pathway (vide infra) involving a coordinative unsaturated $\alpha$-siloxyalkyl intermediate that adds silane and eliminates only $\mathrm{CH}_{3} \mathrm{CH}_{2} \mathrm{OSiR}_{3}{ }^{19}$

Early studies by Akita, Moro-oka, and co-workers 20 coincided with and generally complemented our work on the $\mathrm{Rh}(\mathrm{I})$-catalyzed hydrosilation of $\mathrm{Fp}$ and $\mathrm{Mn}(\mathrm{CO})_{5}$ acyls. (The presence of a rhodium catalyst, however, is unnecessary for the hydrosilation of 1.) ${ }^{15 a}$ Whereas we emphasized the characteriztion of organometallic intermediates and products, they did a nice job on establishing the organic byproducts. For example, they demonstrated that treatment of 1 with excess $\mathrm{Ph}_{2} \mathrm{SiH}_{2}$ and 1 atm. $\mathrm{CO}$ with $1 \% \mathrm{RhCl}\left(\mathrm{PPh}_{3}\right)_{3}$ produced a distribution of alkanes and alkenes reminiscent of FischerTropsch (Pichler-Schulz distribution of) hydrocarbon products emanating from alternate carbonylation/reduction steps. ${ }^{20 a}$ Subsequent studies by the same authors ${ }^{21}$ and others 22 have focused on the hydrosilation-reduction of ligated $\mathrm{CO}$, a topic that is relevant to the present proposal.

The truly unexpected dividend of this research is that these manganese carbonyl alkyl and acyl complexes function as such unusually reactive precatalysts for the reactions of silanes with organic and organometallic substrates. These well-known $\mathrm{Mn}(\mathrm{CO})_{5}$ complexes have not been used previously in 
catalysis; $^{23}$ yet we find them to be far more reactive than traditional $\mathrm{Co}(\mathrm{CO})_{4}$ or even $\mathrm{Rh}(\mathrm{I})$ precatalysts for a variety of reactions between hydrosilanes and $\mathrm{C}=\mathrm{O}^{24}$ or $\mathrm{O}-\mathrm{H}^{25}$ bonds. As noted in the following Objectives summary, these catalytic reactions for organic molecules include:

- dehydrogenative silation of alcohols 25 and carboxylic acids, 26

\begin{tabular}{|c|c|c|c|c|c|}
\hline $\mathrm{R}^{\prime} \mathrm{CH}_{2} \mathrm{OH}$ & + & $\mathrm{R}_{3} \mathrm{SiH}$ & $\rightarrow$ & $\mathrm{R}^{\prime} \mathrm{CH}_{2} \mathrm{OSiR}_{3}$ & + \\
\hline $\mathrm{R}^{\prime} \mathrm{C}(\mathrm{O}) \mathrm{OH}$ & + & $\mathrm{R}_{3} \mathrm{SiH}$ & $\rightarrow$ & $\mathrm{R}^{\prime} \mathrm{C}(\mathrm{O}) \mathrm{OSiR}_{3}$ & \\
\hline
\end{tabular}

- hydrosilation of aldehydes and ketones, ${ }^{24}$ and

$$
\mathrm{R}_{2}^{\prime} \mathrm{C}=\mathrm{O} \quad \mathrm{R}_{3} \mathrm{SiH} \rightarrow \mathrm{R}_{2} \mathrm{CHOSiR}_{3}
$$

- hydrosilation-then-deoxygenation of esters ${ }^{27}$ and silyl carboxylates, ${ }^{26}$ and

$\mathrm{R}^{\prime} \mathrm{C}(\mathrm{O}) \mathrm{OMe}+2 \mathrm{R}_{3} \mathrm{SiH} \rightarrow \mathrm{R}^{\prime} \mathrm{CH}\left(\mathrm{OSiR}_{3}\right)(\mathrm{OMe}) \rightarrow \mathrm{RCH}_{2} \mathrm{OMe}+\left(\mathrm{R}_{3} \mathrm{Si}_{2} \mathrm{O}\right.$

- dehydrogenative silation-then-hydrosilation-then-deoxygenation of carboxylic acids. 26

$$
\mathrm{R}^{\prime} \mathrm{C}(\mathrm{O}) \mathrm{OH}+3 \mathrm{R}_{3} \mathrm{SiH} \rightarrow \mathrm{R}^{\prime} \mathrm{C}(\mathrm{O}) \mathrm{OSiR}_{3} \rightarrow \mathrm{R}^{\prime} \mathrm{CH}\left(\mathrm{OSiR}_{3}\right)_{2} \rightarrow \mathrm{R}^{\prime} \mathrm{CH}_{2} \mathrm{OSiR}_{3}+\mathrm{R}_{3} \mathrm{SiOSiR}_{3}
$$

Organometallic substrates have included predominately iron and manganese acety $\left.\right|^{25,26}$ and benzoy/28 complexes as well as metallocarboxylic acids, ${ }^{29}$ esters, ${ }^{30}$ and silyl esters. ${ }^{31}$

In order to continuously evolve ever more active or selective hydrosilane catalysts, we are studying the reaction chemistry of silanes with manganese alkyl and acyl complexes.

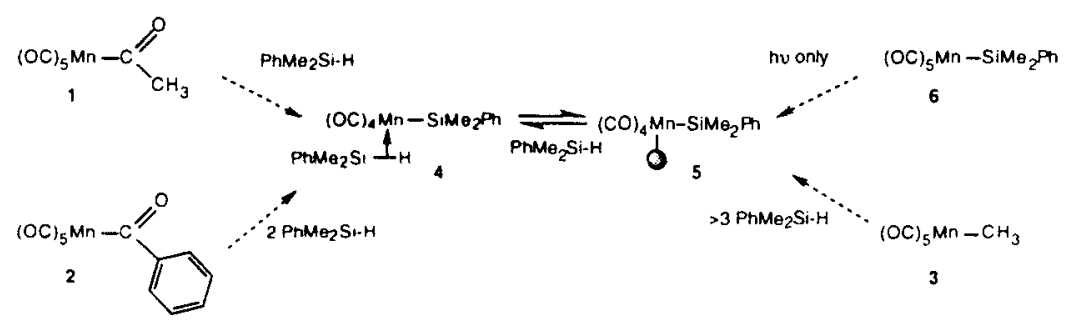

During our prior grant period, we established that the manganese acetyl 1,15b benzoyl 2,28 and methyl $3^{32}$ complexes react with $\mathrm{PhMe}_{2} \mathrm{SiH}$ via very different mechanisms. Under the appropriate conditions all of these reaction mixtures nevertheless afford varying amounts of the same $\left(\eta^{2}-\mathrm{Si}-\mathrm{H}\right)$ silane adduct 4 (which has been characterized in solution ${ }^{32 b}$ ) as the precatalyst for our hydrosilane catalysis chemistry, vide infra. This precatalyst 4 equilibrates with the coordinatively unsaturated manganese silyl 5 , our putative active catalyst.

The coordinatively saturated manganese silyl 6 also provides the active catalyst 5 upon photolysis. 24,27,28,30 A gratifying development is that the silyl intermediates 5 and 6 conform to the active catalyst and resting states, respectively, that we deduced during an earlier kinetics study ${ }^{28 a}$ of isotope exchange between the $\mathrm{EtMe}_{2} \mathrm{SiH}$ and $\mathrm{PhMe} 2 \mathrm{SiD}$ catalyzed by the three precatalysts $1-3$. With the advent of convenient and reproducible sources of $\mathbf{4}$ as precatalyst, we in the process of consolidating our understanding of the manganese carbonyl-catalyzed reactions of silanes with $\mathrm{C}=\mathrm{O}$ and $\mathrm{O}-\mathrm{H}$ bonds. 
OBJECTIVES OF ONGOING AND PROPOSED RESEARCH:

A. Study the reactions of labile $L(C O)_{4} M n$-alkyl, acyl, and halide complexes with hydrosilanes. Our studies of these novel coordinated ligand reactions are being used:

(a) to establish these manganese carbonyl complexes as extremely reactive precatalysts

for the reactions of silanes with organic and organometallic substrates, and

(b) to determine the active catalyst and the plausible mechanisms of this catalysis.

B. Establish the manganese carbonyl-catalyzed hydrosilation-then-deoxygenation of organic ketones and aldehydes and organometallic acyl carbonyl groups.

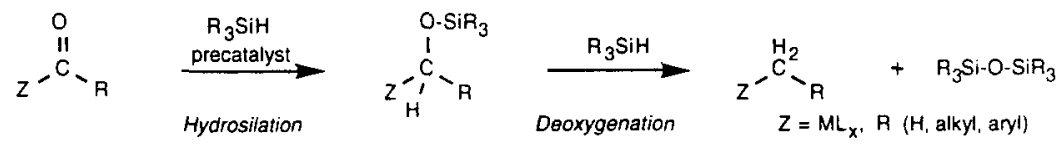

C. Finalize studies on the analogous reduction of the carbonyl group of organic esters. Here the critical issue is controlling the selectivity of the catalytic deoxygenation step to yield either ethers or silyl ethers. Resolution of this issue has depended upon our understanding of the coordinated ligand reactions of the $\mathrm{Mn}$ precatalysts.

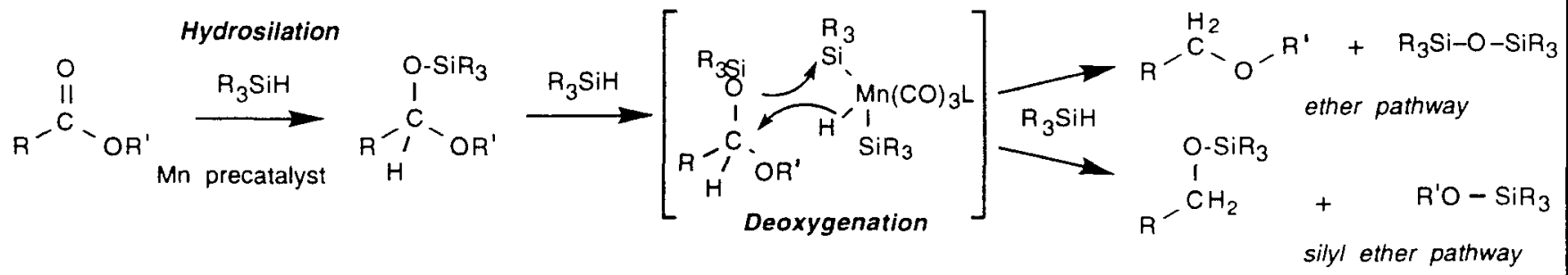

D. Establish the manganese carbonyl-catalyzed dehydrogenative silation-then-hydrosilation-thendeoxygenation of organic carboxylic acid and silyl ester derivatives. Organic formates, $R=H$, represent a special case due to their importance to both $\mathrm{CO}$ and $\mathrm{CO}_{2}$ reduction.

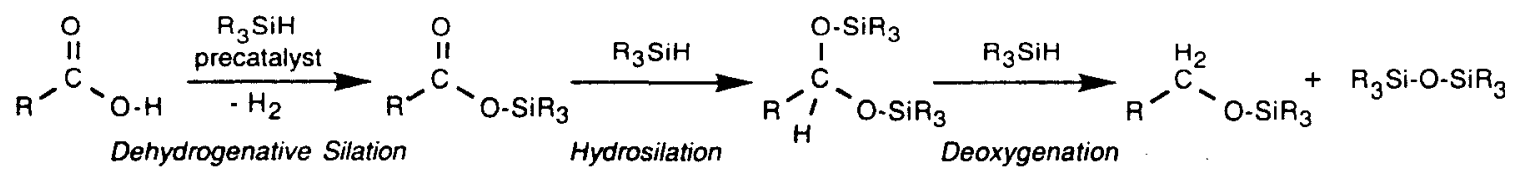

E. Extend the Mn-hydrosilane catalysis of organic carboxylic acids to metallocarboxylic acids and derivatives $L_{x} M C(O) O R\left(R=H, C_{3}, S_{R}\right)$, which are available from either ligated $\mathrm{CO}$ or $\mathrm{CO}_{2}$. This models our metalloester approach to $\mathrm{CO} / \mathrm{CO}_{2}$ fixation: the resulting disilylacetal intermediates $L_{x} M C H\left(\mathrm{OSiR}_{3}\right)_{2}$ serve as alternative $C_{1}$ templates to the usual formyl ligand. $\mathrm{L}_{x} \mathrm{MCO}_{2} \mathrm{H}+4 \mathrm{R}_{3} \mathrm{Si}-\mathrm{H} \rightarrow \mathrm{L}_{x} \mathrm{MCO}_{2} \mathrm{SiR}_{3} \rightarrow\left[\mathrm{L}_{x} \mathrm{MCH}\left(\mathrm{OSiR}_{3}\right)_{2}\right] \rightarrow \mathrm{L}_{x} \mathrm{MCH}_{2} \mathrm{OSiR}_{3} \rightarrow \mathrm{L}_{x} M \mathrm{MCH}_{3}$

F. Explore the possibility of silane-driven hydrogenation of organic and organometallic substrates.

$$
\begin{aligned}
2 \mathrm{R}_{3} \mathrm{Si}-\mathrm{O}-\mathrm{SiR}_{3}+2 \mathrm{H}_{2} & \rightarrow 2 \mathrm{R}_{3} \mathrm{Si}-\mathrm{OH}+2 \mathrm{R}_{3} \mathrm{Si}-\mathrm{H} \\
\mathrm{R}_{2} \mathrm{C}=\mathrm{O}+2 \mathrm{R}_{3} \mathrm{Si}-\mathrm{H} & \rightarrow \mathrm{R}_{2}^{\prime} \mathrm{CH}_{2}+\mathrm{R}_{3} \mathrm{Si}-\mathrm{O}-\mathrm{SiR}_{3} \\
2 \mathrm{R}_{3} \mathrm{Si}-\mathrm{OH} & \rightarrow \mathrm{R}_{3} \mathrm{Si}-\mathrm{O}-\mathrm{SiR}_{3}+\mathrm{H}_{2} \mathrm{O} \\
\mathrm{R}_{2}^{\prime} \mathrm{C}=\mathrm{O}+2 \mathrm{H}_{2} & \rightarrow \mathrm{R}_{2}^{\prime} \mathrm{CH}_{2}+\mathrm{H}_{2} \mathrm{O}
\end{aligned}
$$


B. Reactions of Manganese Carbonyl Alkyl and Acyl Complexes with Hydrosilanes.

1. Manganese Carbonyl Acetyl Reactions with Hydrosilanes and Where It Led.

The thermally labile $(\mathrm{CO})_{5} \mathrm{MnC}(\mathrm{O}) \mathrm{CH}_{3}(1)^{8}$ reacts with 1 equiv. of a monohydrosilane at room temperature in benzene to yield mixtures of $\alpha$-siloxyethyl complexes $(\mathrm{CO})_{5} \mathrm{MnCH}\left(\mathrm{OSiR}_{3}\right) \mathrm{CH}_{3}(8)$ and $\alpha$-siloxyvinyl byproducts $(\mathrm{CO})_{5} \mathrm{MnC}\left(\mathrm{OSiR}_{3}\right)=\mathrm{CH}_{2}(9) .{ }^{15 \mathrm{~b}} \mathrm{PhMe} \mathrm{SiH}_{2}$ and $\mathrm{Et}_{3} \mathrm{SiH}$ were used in for mechanistic studies. Results of reaction profiles (concentration-time plots), for example, are consistent with (1) 8 and 9 formingindependently, and (2) 9 subsequently reacting with hydrosilanes.

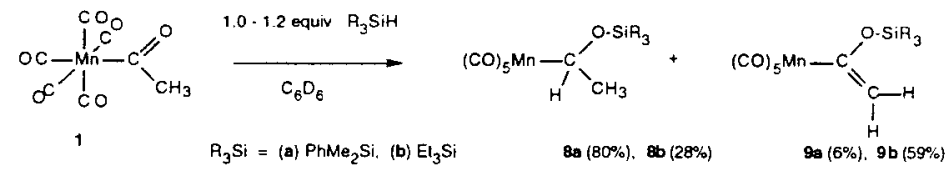

In the presence of excess silane, 8 a degrades to $\left(\mathrm{PhMe}_{2} \mathrm{Si}\right)_{2} \mathrm{O}, \mathrm{Mn}_{2}(\mathrm{CO})_{10}$, and a mixture of organics. The absence of ethoxysilane, vinyl silyl ether, and $(\mathrm{CO})_{5} \mathrm{MnSiMe} 2 \mathrm{Ph}(6 \mathrm{a})$, precludes the intermediacy of the unsaturated $(\mathrm{CO})_{4} \mathrm{MnCH}\left(\mathrm{OSiMe}{ }_{2} \mathrm{Ph}\right) \mathrm{CH}_{3}$ during silane-induced degradation of 8 .

An autocatalysis mechanism accounts for the formation of both 8 and $\mathbf{9}$. Silane-induced degradation of the initially formed 8 provides the unsaturated active catalyst $(\mathrm{CO})_{4} \mathrm{MnSiR}_{3}(5), 33$ which binds 1 and rearranges to the unsaturated $\mu$-siloxyethylidene 10 as the key catalysis intermediate. Silane addition then affords 8 whereas $\beta$-deinsertion produces 9 .

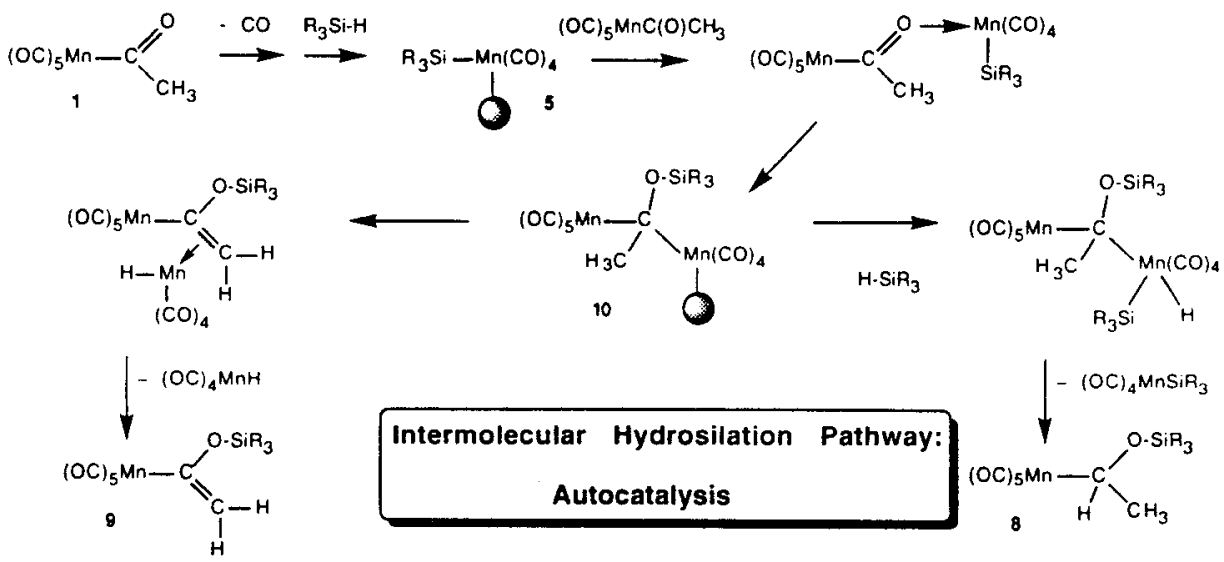

Discerning features of this mechanism include the absence of $(\mathrm{CO})_{5} \mathrm{MnSiR}_{3}, \mathrm{EtOSiR}_{3}$ and $\mathrm{CH}_{2}=\mathrm{CH}\left(\mathrm{OSiR}_{3}\right)$, which preclude transience of unsaturated $(\mathrm{CO})_{4} \mathrm{MnCH}\left(\mathrm{OSiR}_{3}\right) \mathrm{CH}_{3}{ }^{11 \mathrm{a}}$ (the anticipated intramolecular mechanism, vida infra). The induction period required to generate 5 can be removed by pretreating $1 \% 1$ or $(\mathrm{CO})_{5} \mathrm{MnC}(\mathrm{O}) \mathrm{Ph}(2)$ with excess silane for $0.75 \mathrm{~h}$, systems that generate 5 , before adding the substrate 1 . In a previous kinetics study 28 a we demonstrated that the same pretreatment process (starting with either 1 or 2 ) affords an active catalyst for $\mathrm{SiH} / \mathrm{SiD}$ exchange between $\mathrm{Me}_{2} \mathrm{PhSiD}\left(\mathrm{Si}^{\prime} \mathrm{D}\right)$ and $\mathrm{Me} \mathrm{E}_{2} \mathrm{ESiH}(\mathrm{SiH})$.

This isotope exchange focuses on the reactivity of the active catalyst with silane alone. With as little as $0.5 \%$ precatalyst, these exchange reactions afford reproducible induction, pre-equilibrium, and final equilibrium periods. Graphical analysis of Lineweaver-Burk plots for the pre-equilibrium 


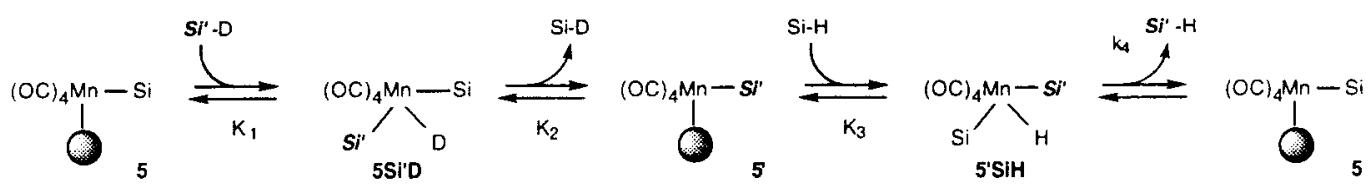

period is in accord with a ping-pong bi bi mechanism that operates under rapid equilibrium conditions and involves unsaturated $(\mathrm{CO})_{4} \mathrm{MnSiMe}_{2} \mathrm{R}\left(4^{\prime}\right)$, as active catalysts.

Although the coordinatively saturated $(\mathrm{CO})_{5} \mathrm{MnSiMe} 2 \mathrm{Ph}(6)$ and $(\mathrm{CO})_{5} \mathrm{MnSiPh} 2 \mathrm{H}$ are not catalyst precursors for SiH/SiD exchange, photolysis of these silyl complexes in the presence of silane engendered efficient isotope exchange. For reasons that will be developed, the resting state $5 \mathrm{SiH}$ intermediates $^{34}$ illustrated presumably equilibrate with $\left(\eta^{2}-\mathrm{Si}-\mathrm{H}\right)$ silane $\mathrm{Mn}$ silyl complexes. ${ }^{35}$

\section{Hydrosilation of the Manganese Aroyl Complexes (CO) ${ }_{5} \mathrm{MnC}(\mathrm{O})-p-\mathrm{C}_{6} \mathrm{H}_{4} \mathrm{Y}$.}

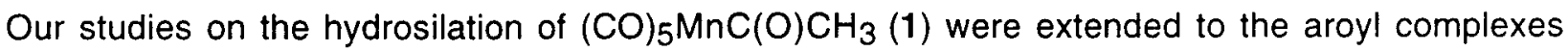
$(\mathrm{CO})_{5} \mathrm{MnC}(\mathrm{O}) \mathrm{C}_{6} \mathrm{H}_{5} \mathrm{Y}\left(2-\mathrm{Y} ; \mathrm{Y}=\mathrm{H}, \mathrm{Me},{ }^{t} \mathrm{Bu}, \mathrm{OMe}, \mathrm{CF}_{3}\right)^{28 \mathrm{~b}}$ for three reasons: (1) The parent benzoyl (2) is among the more active manganese precatalysts. ${ }^{28}$ (2) Preliminary results indicated that 2 and 1 react with hydrosilanes via different pathways. ${ }^{28,4 a}$ (3) Altering the para substituent $Y$ on $2-Y$ alters the electronic environment on the manganese center that could provide mechanistic insight into the hydrosilation process, if not actually change the reaction pathway.

We found that the choice of the aroyl para-substituents had no effect on the rate or outcome of the hydrosilation reactions. All examples of 2-Y consumed 2-3 equiv. of $R_{3} \mathrm{SiH}$ within $1 \mathrm{hr}$. and gavethe $\mathrm{ArCH}_{2} \mathrm{OSiR}_{3}(85-95 \%)$ plus (CO) $\mathrm{MnSiR}_{3}(25-30 \%)$, along with considerable $\mathrm{Mn}_{2}(\mathrm{CO})_{10}$.
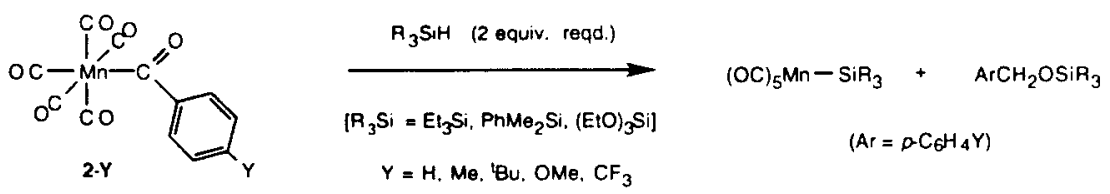

We detected neither $(\mathrm{CO})_{5} \mathrm{MnCH}\left(\mathrm{OSiR}_{3}\right) \mathrm{Ar}$ nor their expected ${ }^{36}$ degradation products $\left[\mathrm{ArCH}\left(\mathrm{OSiR}_{3}\right)\right]_{2}$ (independently prepared). Conducting these reactions with 1.0 equiv. of $\mathrm{R}_{3} \mathrm{SiH}$ left $50 \%$ of the starting 6 and typically gave $\mathrm{ArCH}_{2} \mathrm{OSiR}_{3}$ in $40-45 \%$. Taken together, these and other observations are consistent with an intramolecular hydrosilation mechanism analogous to that proposed for the reactions . of silanes with $\left(\mathrm{PR}_{3}\right)(\mathrm{CO}) \mathrm{CoC}(\mathrm{O}) \mathrm{CH}_{3} \cdot{ }^{19}$ Accordingly, the silane adds to and transfers sequentially from the same metal center to the aroyl ligand undergoing hydrosilation. The resulting unsaturated

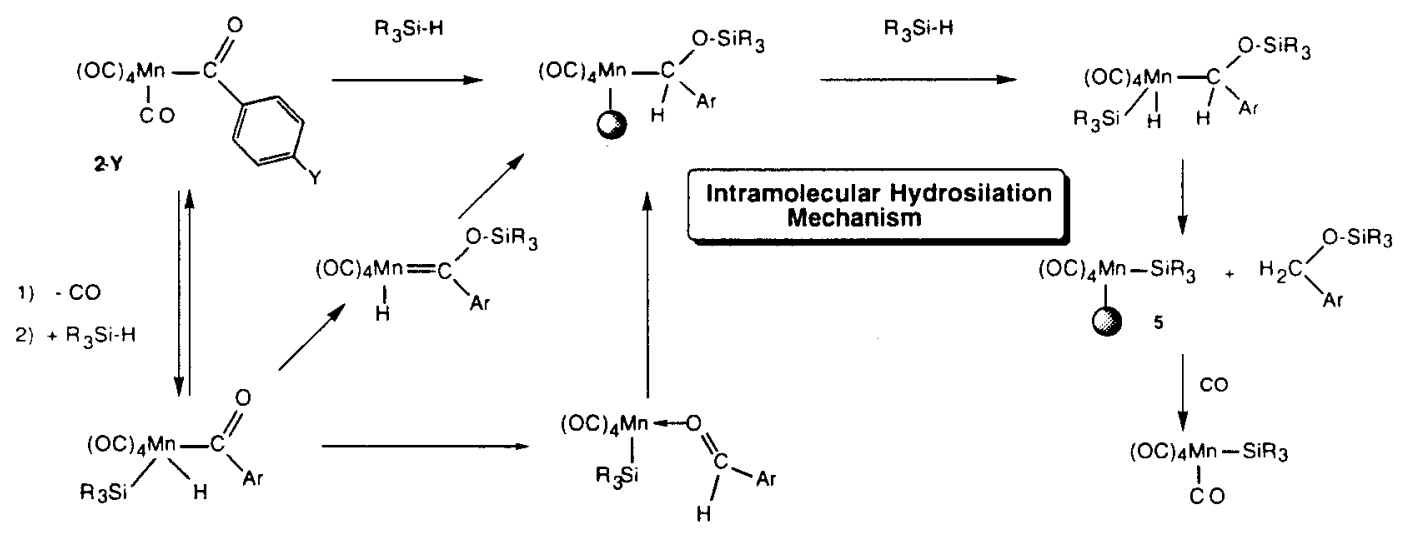


$\alpha$-siloxybenzyl complex adds more silane and degrades to unsaturated 5 plus the observed $\mathrm{ArCH}_{2} \mathrm{OSiR}_{3}$.

\section{Hydrosilane Reactions of the Methyl Complex $(\mathrm{CO})_{5} \mathrm{MnCH}_{3}$ and Congeners.}

This research was initiated because labile manganese alkyl complexes such as $(\mathrm{CO})_{5} \mathrm{MnCH}_{3}(3)$ and $(\mathrm{CO})_{5} \mathrm{MnCH}\left(\mathrm{OSiR}_{3}\right) \mathrm{CH}_{3}(8)$ function as viable - sometimes extremely potent - hydrosilation precatalysts. ${ }^{13}$ Moreover, relatively little was known concerning the reactions of silanes with alkyl complexes. ${ }^{9 b}, 18$ Related chemistry involving $(\mathrm{CO})_{5} \mathrm{MnR}$ includes hydrogenation ${ }^{37}$ and their reactions with manganese hydrides $(\mathrm{L})(\mathrm{CO})_{4} \mathrm{MnH} .^{38}$ Halpern ${ }^{38 a}$ found that these latter reactions comprised several pathways. One particularly relevant pathway is binuclear reductive elimination, which has the manganese-hydride bond promoting alkyl-CO migratory insertion prior to releasing the aldehyde.

Heating 3 and $3-5$ equiv. of $\mathrm{PhMe}_{2} \mathrm{SiH}$ in $\mathrm{C}_{6} \mathrm{D}_{6}$ at $40{ }^{\circ} \mathrm{C}$ for $3 \mathrm{~h}$ or at $24{ }^{\circ} \mathrm{C}$ for $9-10 \mathrm{~h}$ furnished a red solution that contained the new silylmanganese $\left(\eta^{2}-\mathrm{Si}-\mathrm{H}\right)$ silane compound $32 \mathrm{a}, 35$ $(\mathrm{CO})_{4} \mathrm{Mn}\left(\mathrm{H}-\mathrm{SiMe}_{2} \mathrm{Ph}\right) \mathrm{SiMe}_{2} \mathrm{Ph}(4)$. This compound, which collected in $40-55 \%$ yield, has a half life of $12 \mathrm{~h}$ at $22{ }^{\circ} \mathrm{C}$, although removal of the excess silane even at lower temperatures immediately decomposed it. Structure formulation for 4 rests upon the results of ${ }^{1} \mathrm{H},{ }^{13} \mathrm{C},{ }^{29} \mathrm{Si}$ NMR spectroscopy and derivitization experiments. The $\mathrm{Mn}-\mathrm{H}^{1} \mathrm{H}$ NMR spectral resonance at $\mathrm{d}-11.43$ exhibits a ${ }^{2} \mathrm{~J}_{\mathrm{SiH}}=$ $40.0 \mathrm{~Hz}\left({ }^{1} \mathrm{H}\left\{{ }^{29} \mathrm{Si}\right\} \mathrm{HMQC}\right.$ at $\left.-50^{\circ} \mathrm{C}\right)$, and EXSY experiments demonstrated silane exchange with 4.

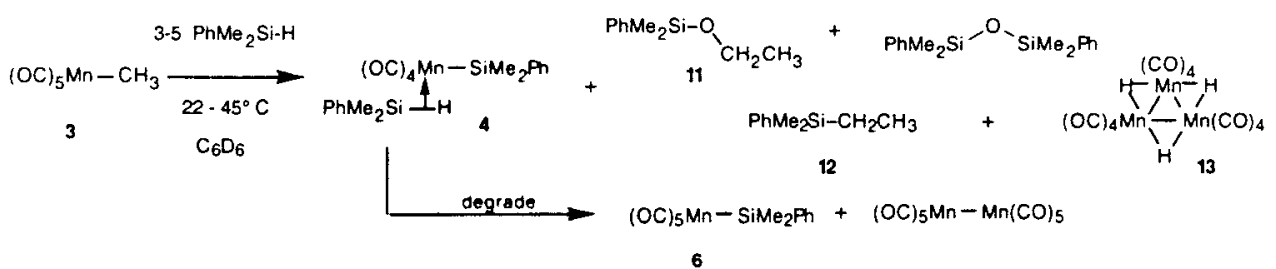

These derivitization experiments are illustrated below. Carbonylation of 4 or treatment with $\mathrm{PPh}_{3}$ quantitatively converted it to the silyl complexes illustrated, and hydrogenation gave the requisite amount of $\left[(\mathrm{CO})_{4} \mathrm{MnH}\right]_{3}(13), 39$ with quantitative release of silane. (Initially, solutions of 4 contained only traces of 6 .)

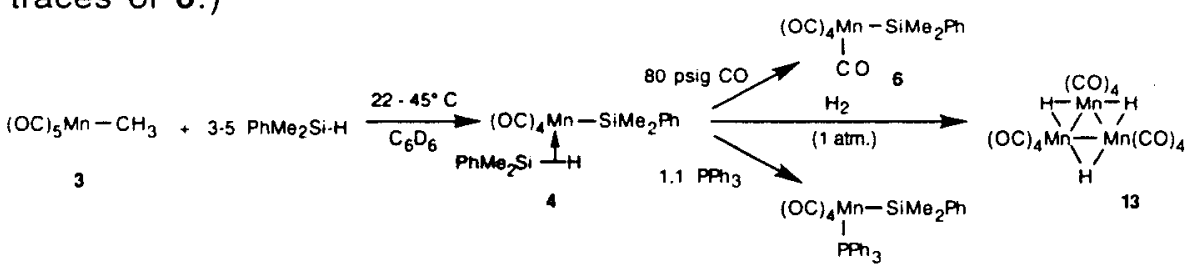

The ethoxysilane 11 and ethylsilane 12 byproducts (maximum 45 and $28 \%$ yields relative to initial 3) that originated along with 4 clearly have incorporated and reduced one ligated carbonyl. When PhMe $2 \mathrm{SiD}$ was used, both 11 and 12 retained $\alpha-C_{2}$ groups. Concentration profiles vs. time are available (NMR spectral quantitation), in addition to IR quantitation of $\mathrm{Mn}_{2}(\mathrm{CO})_{10}$ and $\left[(\mathrm{CO})_{4} \mathrm{MnH}\right]_{3}$ (13) as a function of temperature initial silane and/or 3 concentrations, and the presence of exogenous $\mathrm{CO}$ (1 atm.), $\mathrm{H}_{2}$ (70 psig), or $\mathrm{PPh}_{3}$.

A speculative mechanism appears below that accounts for the formation of the 4 as well as the organosilanes 11 and 12. The excess $\mathrm{PhMe}_{2} \mathrm{SiH}$ promotes methyl-CO migratory insertion, and subsequent reduction (via the intramolecular pathway) produces the $\eta^{2}$-silane adduct of $\alpha$-siloxyethyl 
manganese 14, a branchpoint in the mechanism that leads to 11 and 12 . The pathway leading to 1140 also produces 4 , which however is consumed in the pathway leading to the ethylsilane 12 . This unusual $\mathrm{C}$-Si bond formation 41 could arise via a 4-mediated deoxygenation of 14 involving concurrent hydride transfer with ejection of disiloxane. 42 Subsequent reductive elimination of 12 also releases the manganese trihydride 13.
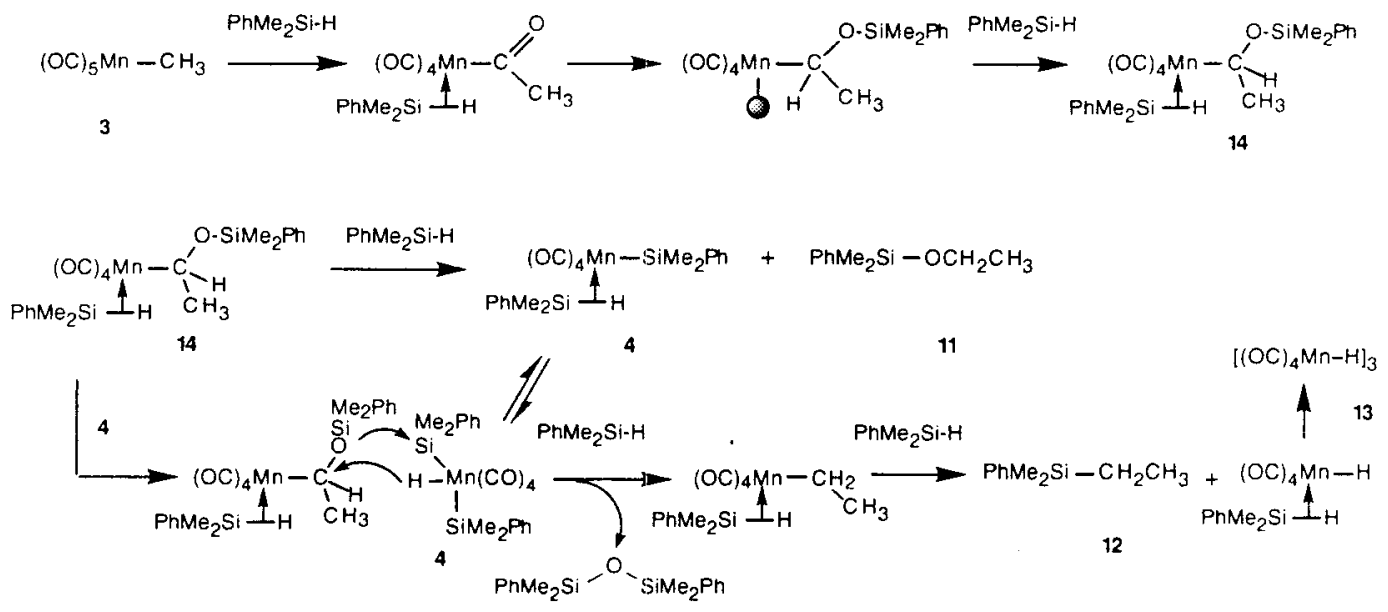

\section{Using $(\mathrm{CO})_{4} \mathrm{Mn}\left(\mathrm{H}-\mathrm{SiMe}_{2} \mathrm{Ph}\right) \mathrm{SiMe}_{2} \mathrm{Ph}$ (4) as the Precatalyst with Silanes.}

We were pleased to find that 4 serves as an extraordinarily active precatalyst for hydrosilane reactions with several substrates. The following examples illustrate successful dehydrogenative silation (acetic acid) and hydrosilation (acetone, ethyl acetate) runs using 4 and either EtMe $\mathrm{SiH}_{2}$ or $\mathrm{Ph}_{2} \mathrm{SiH}_{2}$. Yields are essentially quantitative using less catalyst for significantly faster reactions ( $\leq$ $0.25 \mathrm{hr}$.). Although studies are incomplete for (successful) deoxygenation chemistry, we now have a single precatalyst that efficiently catalyzes all three of these reactions. ${ }^{32 d, 43,44}$ Studies in progress address the efficacy of using solutions containing $1-4 \% 4$ vs. $5 \% 1-3$ as precatalysts for the above catalytic reactions.

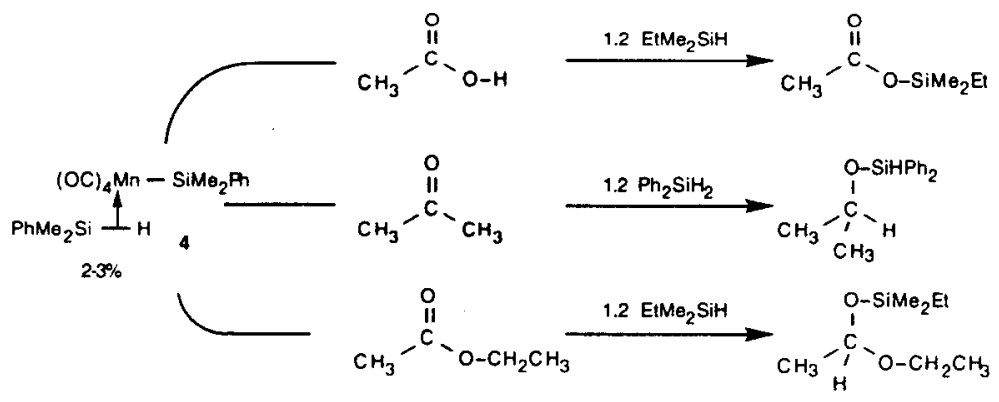

\section{Catalytic Hydrosilation-then-Deoxygenation of Ketones and Organometallic Acyls.}

\section{Manganese Acyl-Catalyzed Hydrosilation of Ketones.}

We compared the relative activity of several manganese precatalysts in $C_{6} D_{6}(2 \mathrm{~mol} \%)$ for

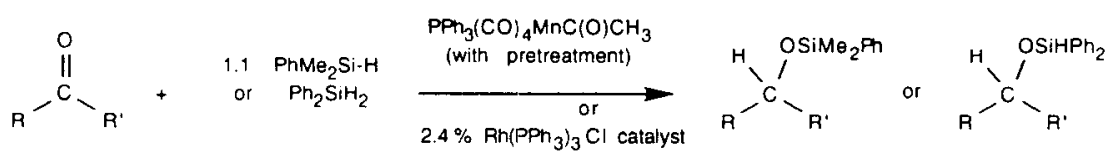

$\left(\mathrm{PPh}_{3}\right)(\mathrm{CO})_{4} \mathrm{MnC}(\mathrm{O}) \mathrm{CH}_{3}(7)(<5 \mathrm{~min})>(\mathrm{CO})_{5} \mathrm{MnC}(\mathrm{O}) \mathrm{Ph}>(\mathrm{CO})_{5} \mathrm{MnC}(\mathrm{O}) \mathrm{CH}_{3}>(\mathrm{CO})_{5} \mathrm{MnCH}_{3}>$ $(\mathrm{CO})_{5} \mathrm{MnBr}(6.0 \mathrm{~h})>\mathrm{Mn}_{2}(\mathrm{CO})_{10} \approx\left(\mathrm{PPh}_{3}\right)(\mathrm{CO})_{4} \mathrm{MnBr} \approx(\mathrm{CO})_{5} \mathrm{MnSiMe} 2 \mathrm{Ph}(6)$. 
catalyzing the hydrosilation of acetone with 1.1 equiv. of $\mathrm{PhMe}_{2} \mathrm{SiH}^{24}$ As a result of this survey, 7 was used in subsequent ketone hydrosilation studies. Pretreating $1 \% 7$ with the full amount of $\mathrm{PhMe}_{2} \mathrm{SiH}$ for $20 \mathrm{~min}$ before adding the ketone decreased the reaction times from $50 \mathrm{~min}$ to $<4 \mathrm{~min}$.

The inert 6 also turned into a moderately effective ketone hydrosilation catalyst during photolysis.

Reaction times using $\mathrm{Rh}\left(\mathrm{PPh}_{3}\right)_{3} \mathrm{Cl}$ (the standard ketone hydrosilation catalyst) ${ }^{4}$ and 7 as precatalysts were compared for the hydrosilation of acetone, acetophenone, and cyclohexanone. Interestingly, 7 was much more active precatalyst for ketone hydrosilation with $\mathrm{PhMe}_{2} \mathrm{SiH}$, although both catalysts exhibited similar activity with $\mathrm{Ph}_{2} \mathrm{SiH}_{2}$. Isolated yields of the alkoxysilanes exceeded $90 \%$, with no evidence of competing dehydrogenative silation to yield vinyl silyl ethers. The manganese 7 hydrosilation systems thus greatly eclipse the ketone hydrosilation activity of the standard $\mathrm{Co}_{2}\left(\mathrm{CO}_{8}\right.$ $/(\mathrm{CO})_{4} \mathrm{CoSiR}_{3}$ and $\mathrm{RhCl}\left(\mathrm{PPh}_{3}\right)_{3}$ catalytic systems in reactivity and product selectivity. 4,45

\section{Manganese Acyl-and $\mathrm{RhCl}\left(\mathrm{PPh}_{3}\right)_{3}$-Catalyzed $\mathrm{PhSiH}_{3}$ Hydrosilation-then-}

\section{Deoxygenation of Organoiron Acyl Complexes $\mathrm{Cp}(\mathrm{L})(\mathrm{CO}) \mathrm{FeC}(\mathrm{O}) \mathrm{R}$.}

Prior to this study the only procedure for reducing an acyl ligand $L_{x} M C(=0) R$ to its alkyl derivative $L_{x} M_{2} H_{2} R$ required using excess $B_{2} H_{6}$ or $\mathrm{BH}_{3} \cdot T H F$, a messy reaction for $\mathrm{Cp}(\mathrm{CO})(\mathrm{L}) \mathrm{Fe}$ acyl

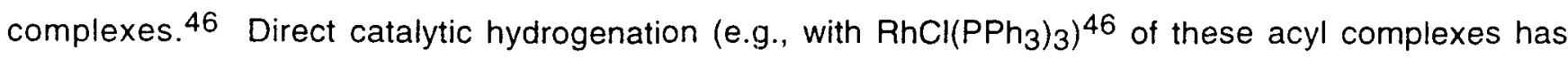
not been documented. Our objective was to find catalytic conditions for the $\mathrm{PhSiH}_{3}$ hydrosilation-thendeoxygenation of $\mathrm{FpCOCH}_{3}(\mathrm{~L}=\mathrm{CO})$ to $\mathrm{FpCH}_{2} \mathrm{CH}_{3}$. ${ }^{16 \mathrm{~b}}$ Initial observations on this reaction using $\mathrm{RhCl}\left(\mathrm{PPh}_{3}\right)_{3}$ catalysis were noted several years ago by Akita and Moro-Oka ${ }^{20}$ and by us. ${ }^{16 a}$ The precatalysts that we studied included $\mathrm{RhCl}\left(\mathrm{PPh}_{3}\right)_{3}$ and the manganese acyls 1,2 , and $7.16 \mathrm{~b}$

With the manganese acyl precatalysts, $\mathrm{FpCOCH}_{3}$ and 1.1 equiv. $\mathrm{PhSiH}_{3}$ transformed to the depicted mono-, bis-, and tris- $\alpha$-siloxyethyl complexes. The initially formed mono- $\mathrm{Fe}$ and bis- $\mathrm{Fe}$ adducts transformed into the tris-Fe compound and $\mathrm{FpCH}_{2} \mathrm{CH}_{3}$. After 12 hours, only the latter compounds remained. The tris-Fe compound did not convert into $\mathrm{FpCH}_{2} \mathrm{CH}_{3}$ under these conditions.

Two extensions of this work are worth noting. First, identical results were obtained by reacting the substrate 1 with $\mathrm{PhSiH}_{3}$ (but without added catalyst). Second the use of $\mathrm{RhCl}\left(\mathrm{PPh}_{3}\right)_{3}(3 \%)$ and

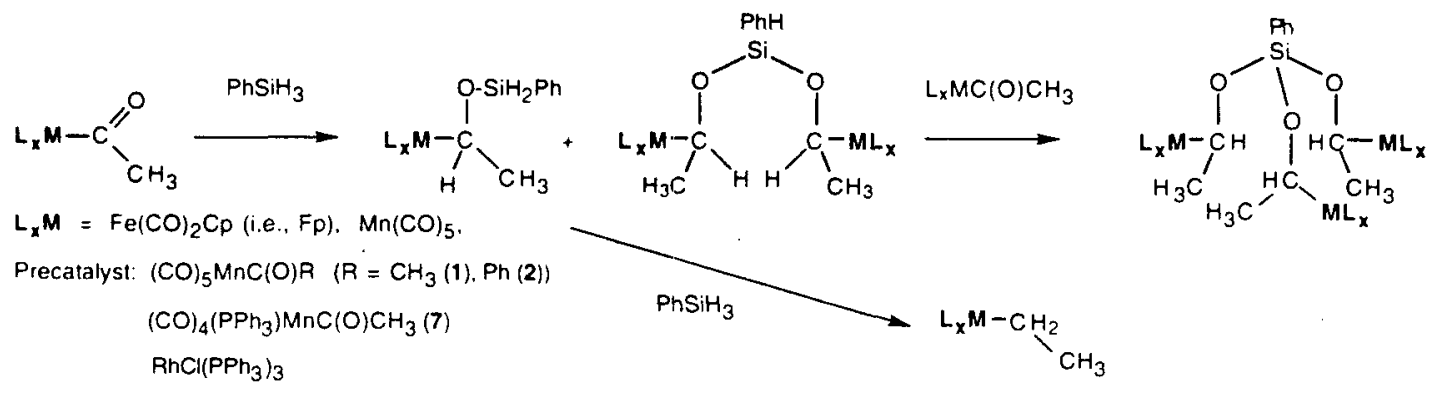

$\mathrm{PhSiH}_{3}$ (1.6 equiv.) is a convenient synthetic procedure for transforming $\mathrm{Cp}(\mathrm{L})(\mathrm{CO}) \mathrm{FeC}(\mathrm{O}) \mathrm{R}$ over 40-60 min. to their alkyl derivatives, $\mathrm{Cp}(\mathrm{L})(\mathrm{CO}) \mathrm{FeCH}_{2} \mathrm{R}$. Seven iron acyls were studied: $[\mathrm{FpC}(\mathrm{O}) \mathrm{R}$, $\mathrm{R}=\mathrm{Me}, \mathrm{Ph}, \mathrm{Pr},{ }^{\mathrm{t}} \mathrm{Bu} ; \mathrm{Cp}(\mathrm{L})(\mathrm{CO}) \mathrm{FeC}(\mathrm{O}) \mathrm{CH}_{3}, \mathrm{~L}=\mathrm{PPh}_{3}, \mathrm{P}(\mathrm{OMe})_{3}$, and $\left.\mathrm{P}(\mathrm{OPh})_{3}\right]$.

An important outcome of this study were early examples of using silane catalysis to fully reduce an acyl group. The hydrosilation of the Fp acyls resembles $\mathrm{Rh}^{4}$ - or $\mathrm{Mn}^{24,27}$-catalyzed hydrosilation 


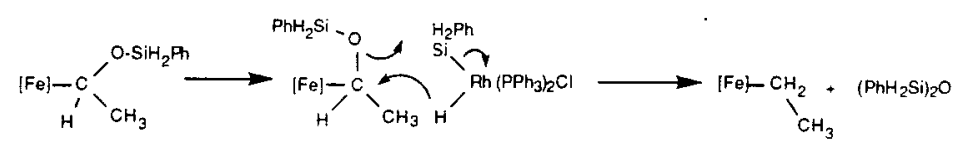

of ketones, whereas the deoxygenation step apparently entails hydride transfer from a hydrosilane adduct of the active catalyst commensurate with disiloxane, vide infra.

\section{Manganese Acyl Catalyzed Hydrosilation-then-Deoxygenation of Esters.}

The manganese acetyls $(\mathrm{L})(\mathrm{CO})_{4} \mathrm{MnC}(\mathrm{O}) \mathrm{CH}_{3}\left[\mathrm{~L}=\mathrm{CO}(1), \mathrm{PPh}_{3}(7)\right]$ catalyze the $\mathrm{PhSiH}_{3}$ hydrosilation-then-deoxygenation of esters $\mathrm{RC}(=\mathrm{O}) O \mathrm{R}^{\prime}$ to ethers and in some cases to silylether products. ${ }^{27}$ By using $\mathrm{Ph}_{2} \mathrm{SiH}_{2}$ and $\mathrm{PhMe}_{2} \mathrm{SiH}$, we demonstrated that the initial ester hydrosilation step forms a silyl acetal $\mathrm{RCH}\left(\mathrm{OSiR}_{3}\right) \mathrm{OR}$ ', which upon treatment with $\mathrm{PhSiH}_{3}$ or even $\mathrm{Ph}_{2} \mathrm{SiH}_{2}$ undergoes further catalytic deoxygenation. This last step yields ether and silylether $\left(\mathrm{RCH}_{2} \mathrm{OSiR} 3\right.$ and $\left.\mathrm{R}^{\prime} \mathrm{OSiR} \mathrm{Si}_{3}\right)$ products. The following scheme illustrates these competing catalytic deoxygenation pathways. $27,47,48$

Choice of the precatalyst affects this partitioning of deoxygenation pathways. Ethyl acetate, for example, with $\mathrm{PhSiH}_{3}$ (1.2 equiv) and 7 (1.5\%) underwent an exothermic reaction that yielded $85 \%$ $\mathrm{Et}_{2} \mathrm{O}$ [and $\mathrm{PhSiH}(\mathrm{OEt})_{2}$ ] within $15 \mathrm{~min}$; the same reaction but using 1 as the precatalyst went slower
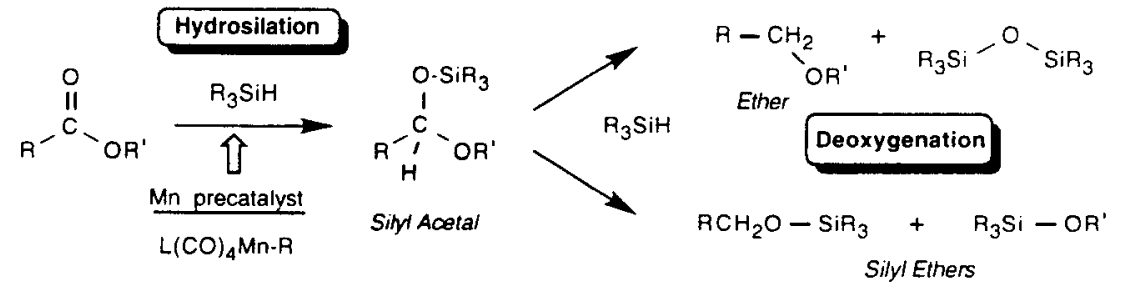

$(1.5 \mathrm{~h})$, but quantitatively provided $\mathrm{Et}_{2} \mathrm{O}$. Analogous reactions using $\mathrm{Ph}_{2} \mathrm{SiH}_{2}$ and $\mathrm{PhMe}_{2} \mathrm{SiH}$ afforded silyl acetals (80-90\% isolated yields), which underwent further 7-catalyzed reduction to ether with $\mathrm{PhSiH}_{3}$ or even $\mathrm{Ph}_{2} \mathrm{SiH}_{2}$.

The mechanism for this ester-hydrosilane catalysis consists of the two steps, hydrosilation and then deoxygenation. We envisage hydrosilation starting with $\mathbf{5}$ as the active catalyst and following a pathway analogous to ketone hydrosilation. 24,4 The deoxygenation step, 49 however, with its partitioning between between ether and silyl ether products remains the subject of ongoing study. Our current working hypothesis involves 5SiH, the hydrosilane adduct of the active catalyst, ${ }^{34}$ as a hydride donor to the silyl acetal commensurate with release of disiloxane (or silyl ether). ${ }^{15,16 b, 50}$

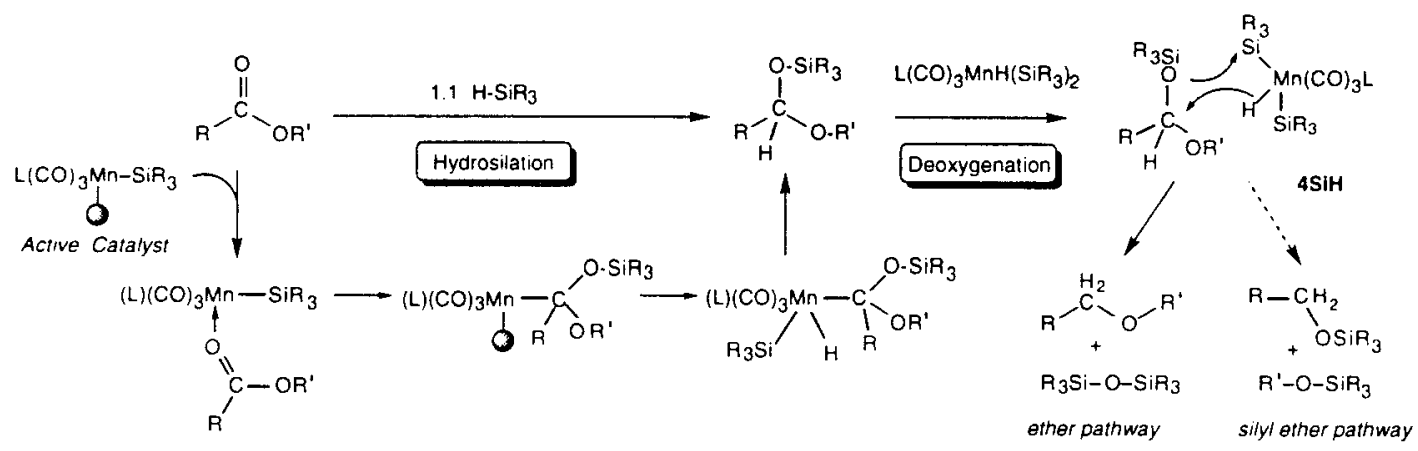




\section{Catalytic Hydrosilation-then-Reduction of "Difficult" Esters.}

In our initial studies, 1- and 7-catalyzed $\mathrm{PhSiH}_{3}$ reactions with selected esters and lactones gave $40-95 \%$ yields of ethers and only minor amounts of silyl ether byproducts. ${ }^{27}$ Although virtually all esters tested were consumed under our catalysis conditions, some provided complex mixtures of silyl acetals, silyl ethers, and relatively small amounts of ethers. Ethyl formate and methyl $p$-toluate are typical of these "difficult" esters that we further studied. 50

Our objective was to document the relative amounts of ester-derived ethers, silyl ethers, and silyl acetals as a function of hydrosilane, manganese precatalyst, and reaction conditions. Ultimately, this information coupled with anticipated advances in catalyst design for promoting these esterhydrosilane reactions should permit us to transform virtually any ester selectively to its ether or silyl ether products.

A sampling of data for ethyl formate illustrates the complexity of the 7 -catalyzed reaction with $\mathrm{PhSiH}_{3} .{ }^{51}$ (Under comparable conditions, $\mathrm{CH}_{3} \mathrm{CO}_{2} \mathrm{Et}$ yielded $84 \%$ ether plus $8 \%$ bis-silyl ether, $\mathrm{PhSiH}(\mathrm{OEt})_{2}$.) The relative concentrations of these silyl acetals varied with the $\mathrm{PhSiH}_{3}$ present and reaction time, but the amount of ether remained $<10 \%$. Since we could not isolate the mono- and bissilyl acetals, analogs were synthesized using $\mathrm{Ph}_{2} \mathrm{SiH}_{2}$ and $\mathrm{PhMeSiH}_{2}$ and used as spectroscopic models.

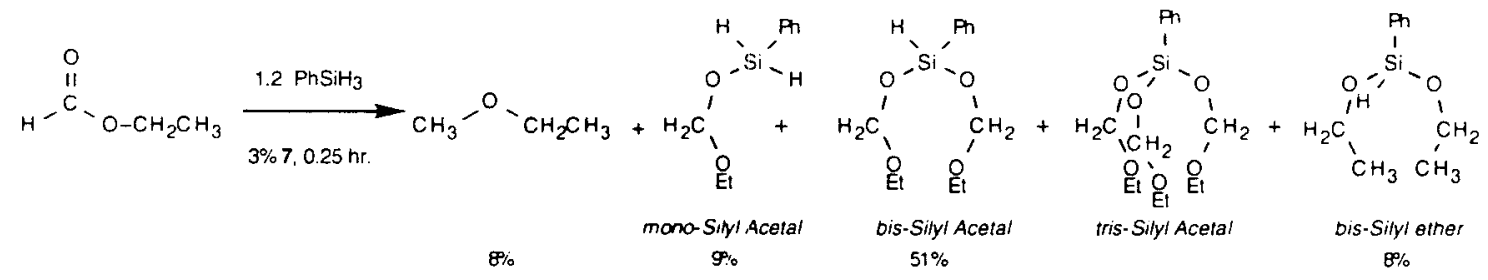

The apparent resistance of bis- and tris-silyl acetals towards catalytic deoxygenation by silanes ${ }^{16}$ led us to examine the reactivity of fully characterized monosilyl acetals. $\mathrm{PhMe}_{2} \mathrm{SiOCH}_{2} \mathrm{OEt}$ and $\mathrm{EtMe}_{2} \mathrm{SiOCH}_{2} \mathrm{OEt}^{52}$ accordingly were treated with 1.2 equiv. of different silanes and manganese precatalysts; a sampling of this data appears below for $\mathrm{EtMe}_{2} \mathrm{SiOCH}_{2} \mathrm{OEt}$. Two conclusions emerge from this data. First, the expected deoxygenation regioselectivity was confirmed with $\mathrm{PhMe}_{2} \mathrm{SiH}$ : the mixed

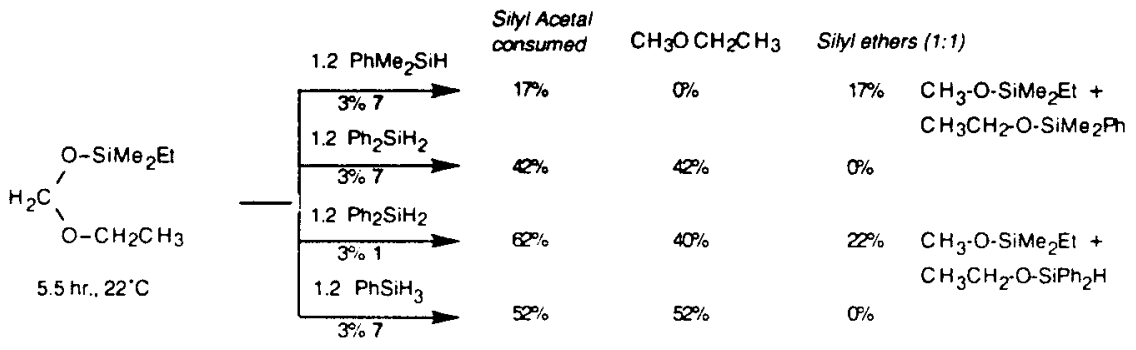

silyl ethers $\mathrm{CH}_{3} \mathrm{OSiMe}_{2} \mathrm{Ph}$ and $\mathrm{CH}_{3} \mathrm{CH}_{2} \mathrm{OSSMe}_{2} \mathrm{Et}$ were not detected. Second, the facility of 7-catalyzed deoxygenation of a monosilyl acetal to yield its organic ether increases: $\mathrm{PhSiH}_{3}>\mathrm{Ph}_{2} \mathrm{SiH}_{2}>\mathrm{PhMe}_{2} \mathrm{SiH}$.

These conclusions can be generalized: the choice of both the hydrosilane and the precatalyst are important in selectively converting a silyl acetal to its ether or silyl ether products. Selectively transforming a monosilyl acetal into an ether requires generating the silylacetal with $\mathrm{PhMe}_{2} \mathrm{SiH}$ and catalytically deoxygenating it with $\mathrm{PhSiH}_{3}$. Attempts to use just $\mathrm{Ph}_{2} \mathrm{SiH}_{2}$ or $\mathrm{PhSiH}_{3}$ for both catalytic 
steps invariably produces bis- and tris-silyl acetals, which resist subsequent deoxygenation. Although $\mathrm{RMe}_{2} \mathrm{SiH}$ readily forms monosilyl acetals, they do not further react with monohydrosilanes.

\section{Rhodium(I)-Catalyzed Hydrosilation of Organic Esters.}

Although rhodium(I)-catalyzed hydrosilation of aldehydes and ketones represents a mature technology, ${ }^{4}$ similar hydrosilation of simple organic esters is unknown. ${ }^{47,48}$ We were therefore quite surprised to find that in "control" experiments even Wilkinson's catalyst promoted the diphenylsilane hydrosilation of ethyl acetate. The presence of $3 \% \mathrm{RhCl}\left(\mathrm{PPh}_{3}\right)_{3}$ and 2.4 equiv. of $\mathrm{Ph}_{2} \mathrm{SiH}_{2}$ quantitatively transforms ethyl acetate to ether over $48 \mathrm{~h}$, whereas $\left[\mathrm{Rh}\left(\mathrm{O}_{2} \mathrm{CCH}_{3}\right)(\mathrm{COD})\right]_{2},{ }^{53}$ stops at the monosilyl acetal stage $(88 \%, 0.3 \mathrm{~h})$.

This $\mathrm{Rh}(\mathrm{I})$ catalysis study has relied on just a few precatalysts - $\mathrm{RhCl}\left(\mathrm{PPh}_{3}\right)_{3},[\mathrm{RhCl}(\mathrm{COD})]_{2}$, $[\mathrm{RhCl}(\mathrm{COD})]_{2}+2 \mathrm{PPh}_{3}$, and $\left[\mathrm{Rh}\left(\mathrm{O}_{2} \mathrm{CCH}_{3}\right)(\mathrm{COD})\right]_{2}, 53$ - and ethyl acetate, ethyl formate, and methyl p-toluate as substrates. Under all conditions, $\mathrm{PhMe} 2 \mathrm{SiH}$ and $\mathrm{Et}_{3} \mathrm{SiH}$ were unreactive, whereas . $\mathrm{Ph}_{2} \mathrm{SiH}_{2}$ (and $\mathrm{Et}_{2} \mathrm{SiH}_{2}$ and $\mathrm{PhMeSiH}_{2}$ in preliminary studies) underwent facile hydrosilation reactions.

Thus far, we only have results from ${ }^{1} \mathrm{H},{ }^{13} \mathrm{C}$ NMR spectral monitoring, which needs to be supplemented by GC quantitation and preparative work for selected catalytic runs. The more volatile dihydrosilanes $\mathrm{Et}_{2} \mathrm{SiH}_{2}, \mathrm{PhMeSiH}_{2}$, and $\mathrm{EtMeSiH}_{2}$ represent good candidates for these studies. We believe that it would be propitious to survey a few (Rh(l) for now) catalytic systems that also are promising for $\mathrm{CO}_{2}$ hydrogenation. ${ }^{54}$ Examples of such catalytic systems include [(dppb)RhH $]_{x}$ and $[(\mathrm{cod}) \mathrm{RhH}]_{4}{ }^{55}$ as well as an eclectic selection of Wilkinson catalyst analogs, including replacement of the $\mathrm{PPh}_{3}$ by $\mathrm{PMe}_{3}, \mathrm{PiPr}_{3}$, etc. 56

\section{E. Catalytic Reactions of Hydrosilanes with Carboxylic Acids and Silyl Carboxylates.}

We have extended the manganese carbonyl-hydrosilane catalysis to carboxylic acids using formic, acetic, toluic, and (less extensively) phenylacetic acids as the substrates. By balancing the choice of hydrosilane and precatalyst, we selectively converted these carboxylic acids into their silyl esters, their disilyl acetals, $\mathrm{RCH}\left(\mathrm{OSiR}_{3}\right)_{2}$, and finally their alkoxysilanes, $\mathrm{RCH}_{2} \mathrm{OSiR}_{3} \cdot{ }^{26}$

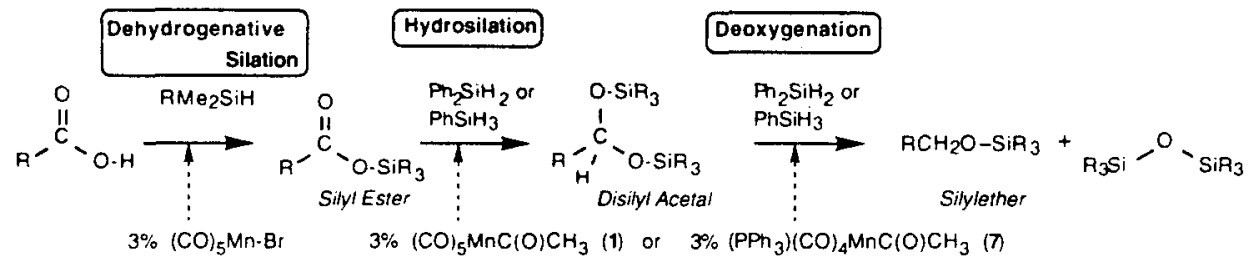

This product selectivity depends upon matching the appropriate precatalyst and silane for each of the above three catalytic steps. The dehydrogenative silation reaction selectively forms the silyl ester 57 (even with excess $\mathrm{RMe}_{2} \mathrm{SiH}, \mathrm{R}=\mathrm{Et}, \mathrm{Ph}$ ) with (CO) ${ }_{5} \mathrm{MnBr}$ precatalyst. Formation of the disilyl acetals is best carried out using either 1 or 7 as the precatalyst with $\mathrm{RMe}_{2} \mathrm{SiH}$ and either the acid or its silyl ester. 58 The more reactive $\mathrm{PhSiH}_{3}$ was used in the third or deoxygenation step along with 7 as the precatalyst. By using $\mathrm{PhSiH}_{3}$ and 7 , we for example quantitatively converted $\mathrm{CH}_{3} \mathrm{CO}_{2} \mathrm{SiMe}_{2} \mathrm{Et}$ to a mixture of silyl ethers, EtOSiMe $\mathrm{Et}$ and $\mathrm{PhSiH}_{\mathbf{x}}\left(\mathrm{OCH}_{2} \mathrm{CH}_{3}\right)_{3-x} \cdot{ }^{58}$ 
We are interested in the catalytic dehydrogenative silation, hydrosilation, and deoxygenation of formic acid as a novel approach to $\mathrm{CO}$ and $\mathrm{CO}_{2}$ reduction. Previous work of Klinger and Rathke 59 established uncatalyzed chemistry in which the disiloxane $\mathrm{Me}_{3} \mathrm{SiOSiMe}_{3}$ and $\mathrm{H}_{2}$ under pressure at 250 ${ }^{\circ} \mathrm{C}$ with $\mathrm{CO}$ or $\mathrm{CO}_{2}$ yielded $\mathrm{Me}_{3} \mathrm{SiOCH}_{3}$ and $\mathrm{HCO}_{2} \mathrm{CH}_{3}$ as the final products. A silyl formate $\mathrm{HCO}_{2} \mathrm{SiMe}_{3}$ evidently mediates this chemistry and is converted to the hypothesized disilylacetal $\mathrm{CH}_{2}\left(\mathrm{OSiMe}_{3}\right)_{2}$ that extrudes $\mathrm{CH}_{2}=\mathrm{O}$. This intriguing chemistry is discussed further in the Proposed Studies.

Our immediate objective was to see if we could extend our mild catalysis conditions to convert formic acid via its uncharacterized disilylacetal to methoxysilanes. These studies then will be expanded to (a) thermal degradation of disilylacetals and (b) catalytic disiloxane hydrogenation as a silane plus silanol source coupled with (c) catalytic hydrosilation of $\mathrm{CO}_{2}$ and $\mathrm{CO}$, respectively (vide infra).

The manganese-catalyzed hydrosilation of formic acid resembles that of ethyl formate rather than acetic acid. ${ }^{32 b}$ We obtained the silyl formates $\mathrm{HCO}_{2} \mathrm{SiR}_{3}\left[\mathrm{SiR}_{3}=\mathrm{SiMe} \mathrm{Et}_{2}, \mathrm{SiEt}_{2} \mathrm{Me}, \mathrm{SiMe}_{2} \mathrm{Ph}\right.$, and SiHPh 2 ] and disilyl acetals $\mathrm{CH}_{2}\left(\mathrm{OSiR}_{3}\right)_{2}\left[\mathrm{SiR}_{3}=\mathrm{SiMe} \mathrm{Et}_{2}, \mathrm{SiMe}_{2} \mathrm{Ph}\right.$, and $\left.\mathrm{SiMe}_{2} \mathrm{Et} / \mathrm{SiHPh}_{2}\right]$ using the above reaction chemistry. Treatment of $\mathrm{HCO}_{2} \mathrm{SiMe}_{2} \mathrm{Ph}$ with 1.2 equiv. of $\mathrm{PhSiH}_{3}$ and $3 \% 7$ provided < $10 \% \mathrm{CH}_{3} \mathrm{OSiMe}_{2} \mathrm{Ph}$ - most of the product is the bis-disilyl acetal $\mathrm{PhSiH}\left(\mathrm{OCH}_{2} \mathrm{OSiMe}_{2} \mathrm{Ph}\right)_{2}$. Catalytic deoxygenation of preformed $\mathrm{CH}_{2}\left(\mathrm{OSiMe}_{3}\right)_{2}$ was more useful. The yields of $\mathrm{CH}_{3} \mathrm{OSiMe} 2 \mathrm{Ph}$ depended on the hydrosilane used in the second step: $\mathrm{PhSiH}_{3}(51 \%), \mathrm{Ph}_{2} \mathrm{SiH}_{2}(23 \%)$, and $\mathrm{PhMe} 2 \mathrm{SiH}(9 \%)$.

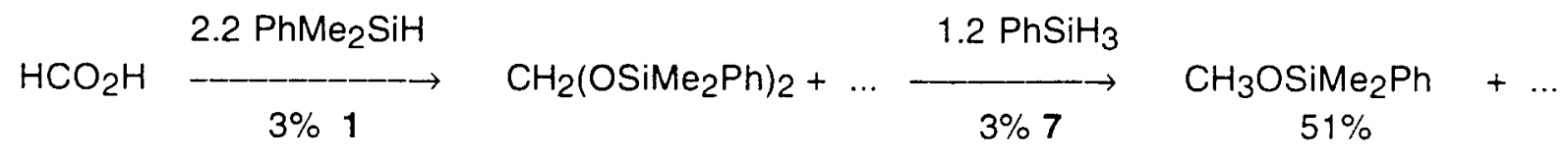

\section{F. Catalytic Reactions of Hydrosilanes with Metallocarboxylic Acid Derivatives.}

Metallocarboxylic acids $\mathrm{L}_{x} \mathrm{MC}(\mathrm{O}) \mathrm{OH}$ have an established role in catalysis, for example, the water-gas shift-reaction. $60 \mathrm{In}$ this and other reactions they mediate the $\mathrm{pH}$-dependent interconversion of ligated $\mathrm{CO}$ nd $\mathrm{CO}_{2}$. Although several metallocarboxylic acids have been fully characterized, 61 most are unstable with respect to $\mathrm{CO}_{2}$ deinsertion and conversion to metal hydrides. (Metalloester derivatives, alkoxycarbonyl complexes, are relatively stable and are available from ligated $\mathrm{CO}$ or . $\left.\mathrm{CO}_{2}.\right)^{62}$ Very little is known however concerning the reduction of the acyl ligand of metallocarboxylic acids and their ester derivatives. 63,64

We suspect nonetheless that metallocarboxylic acids and their derivatives could be involved in $\mathrm{CO}$ or $\mathrm{CO}_{2}$ fixation. ${ }^{1 a}, 64$ Consider the hypothetical hydrogenation of a metallocarboxylic acid to yield 15, the hydrate of the formyl $L_{x} M C(O) H$. This acetal derivative could supplant the ubiquitous formyl ligand as a $\mathrm{C}_{1}$ template for converting ligated $\mathrm{CO}$ (or $\mathrm{CO}_{2}$ ) to a hydroxymethyl ligand. Although there are no examples of 15 , several acetal analogs have been reported. 65 We previously reported 64 that $\mathrm{Cp}(\mathrm{CO})_{2} \mathrm{FeCH}(\mathrm{OMe})_{2}$, which is stable at room temperature as opposed to the very unstable $\mathrm{FpC}(\mathrm{O}) \mathrm{H},{ }^{1 \mathrm{a}}$ could be reduced to $\mathrm{FpCH}_{2} \mathrm{OMe}$.

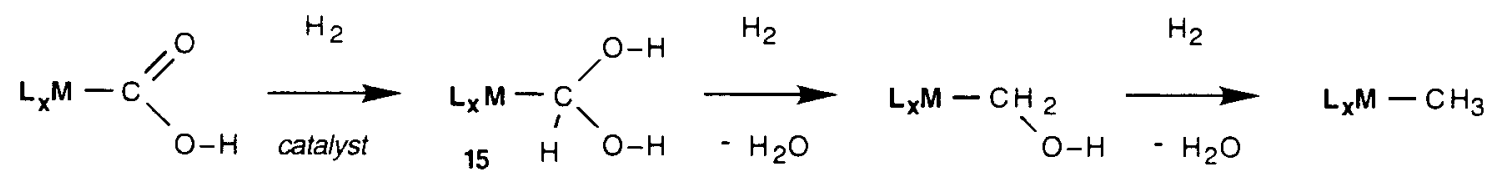


Our objective was to extend our hydrosilane catalysis to metallocarboxylic acids and their esters, thus (catalytically) transforming them to siloxymethyl complexes, $\mathrm{L}_{x} \mathrm{MCH}_{2} \mathrm{OSiR}_{3}{ }^{66}$ Results of our initial hydrosilation survey of metalloesters $\mathrm{L}_{x} \mathrm{MCO}_{2} \mathrm{CH}_{3}$ was disappointing: 30 these compounds proved to be much less reactive than their acetyl analogs. Under conditions where $(\mathrm{CO})_{5} \mathrm{MnC}(\mathrm{O}) \mathrm{CH}_{3}$ (1) underwent hydrosilation, $(\mathrm{CO})_{5} \mathrm{MnC}(\mathrm{O}) \mathrm{OCH}_{3}$, for example, was inert towards $\mathrm{Ph}_{2} \mathrm{SiH}_{2}$. Attempts to promote its hydrosilation using 1,7 , or $\mathrm{Rh}(\mathrm{l})$ catalysis also failed. 30

We did develop the above ligand reactions by using the nonlabile system $L_{x} M=C p^{*}(C O)(N O) R e$ as its carboxylic acid $16^{67}$ and silyl ester $17^{68}$ complexes. Choice of a nonlabile rhenium center ensured that intermolecular hydrosilane reactions were centered on the $C_{1}$ carboxylate ligand. 29,31

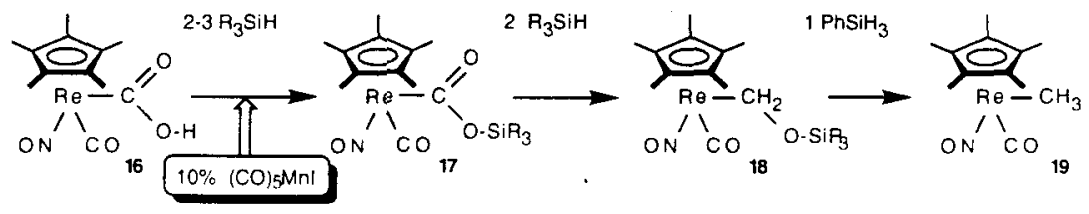

Three themes emerged from these studies. (1) (CO) $5 \mathrm{Mnl}(20)$ is a surprisingly effective precatalyst for hydrosilation then deoxygenation of 16 and 17 . (2) these ligand reactions differ significantly from similar catalytic reactions involving their organic carboxylic acid analogs. (3) as illustrated, either 16 or 17 can be catalytically reduced with hydrosilanes to the siloxymethyl 18 and methyl 19 complexes. This represents a rare example of using a homogeneous catalytic system to reduce carbon monoxide ligated - as its siloxycarbonyl derivative - at another metal complex. 69

\section{The Catalytic Hydrosilation and Further Reduction of Rhenium Silyl Esters.}

The silyl esters $\mathrm{Cp}^{*}(\mathrm{CO})(\mathrm{NO}) \mathrm{ReCO}_{2} \mathrm{SiR}_{3} 68$ (17) serve as substrates towards 20-catalyzed hydrosilation-then-deoxygenation. ${ }^{31}$ With $5 \% 20$ present, 17a in $\mathrm{C}_{6} \mathrm{D}_{6}$ plus 2.5 equiv. of $\mathrm{PhMe}_{2} \mathrm{SiH}_{\mathrm{H}}$ transformed within 3-4 hours to the siloxymethyl complex 18a (89-94\%) plus disiloxane 22a. No intermediates were detected by NMR spectroscopy. The same reaction at $50^{\circ} \mathrm{C}$ required only $1 \mathrm{hr}$.

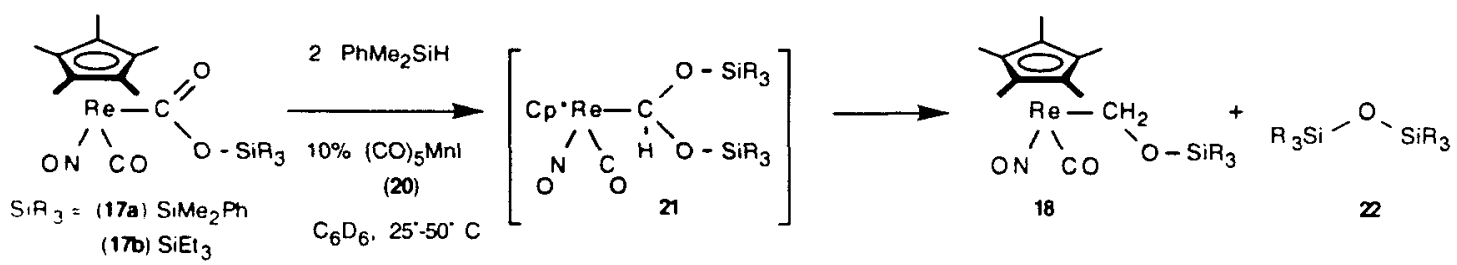

By examining concentration-time profiles for these reactions, we demonstrated that two equiv. of $\mathrm{PhMe} 2 \mathrm{SiH}$ are required to consume $17 \mathrm{a}$ and simultaneously produce $18 \mathrm{a}$ plus 22a. Although we had isolated organic disilylacetals, we did not detect 21 with the present precatalyst 20 and choices of silane. Further studies using crossover experiments - e.g., treatment of 17a with 2.0 equiv. of $\mathrm{Et}_{3} \mathrm{SiH}$ - uncovered an intriguing 20-catalyzed silyl exchange reaction for silyl esters 17 (but not for 18 or

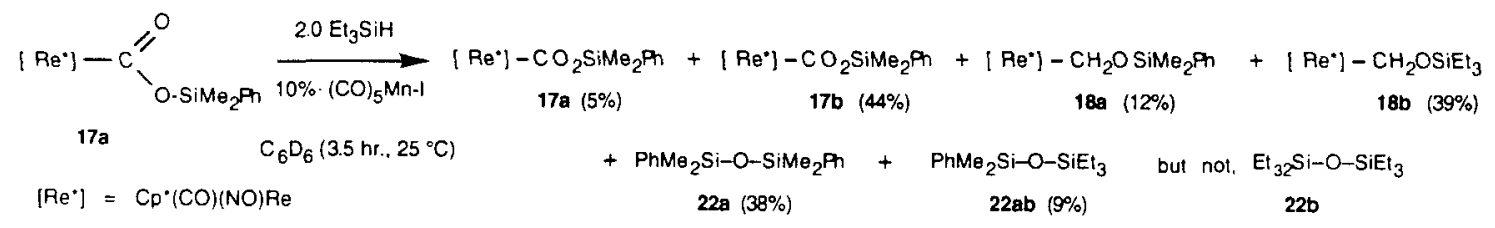


22). Yields correspond to starting 21a. Taken togeather, these results conform to a mechanism involving reversible formation of disilylacetal intermediates 21 and then subsequent deoxygenation of to yield the siloxymethyl 1870,71

The use of the more reactive $\mathrm{PhSiH}_{3}$ in 20 -catalyzed reactions with $17 \mathrm{a}$ and $17 \mathrm{~b}$ yielded the fully reduced methyl complex 19 . Thus use of $\mathrm{PhSiH}_{3}$ in $(\mathrm{CO})_{5} \mathrm{Mnl}(10 \%)$ catalyzed reactions with 17 a yielded up to $45 \% 19$.

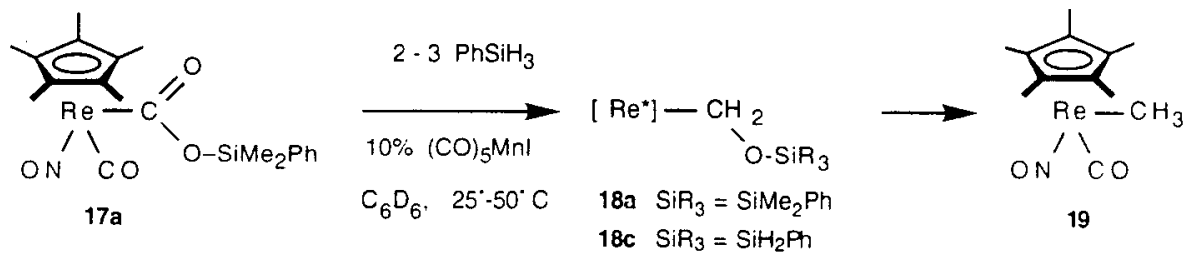

Perhaps the most important conclusion is that the putative disilylacetal complexes 21 can undergo reactions that are not available to their formyl analogs. We showed in this study that the formyl $\mathrm{Cp}^{*}(\mathrm{CO})(\mathrm{NO}) \mathrm{ReCHO}$ did not undergo catalytic hydrosilation. ${ }^{31}$

\section{The Case for the Hemisilylacetal Pathway for Catalytic Hydrosilation and Deoxygenation of a Rhenium Carboxylic Acid.}

Reactions involving the rhenium acid 16 $16^{67}, 2.5-3.0$ equiv of $\mathrm{PhMe} 2 \mathrm{SiH}$, and $5 \mathrm{~mol} \%$ of precatalyst 20 required more than $24 \mathrm{hrs}$. at $22^{\circ} \mathrm{C}$ or $3-4 \mathrm{hrs}$. at $50^{\circ} \mathrm{C}$ to convert all of the 16 to $18 \mathrm{a} .29$ The relative slowness of this acid reaction vs. that of its silyl ester $17 \mathrm{a}$ is particularly intriguing in that $17 \mathrm{a}$ appeared as an intermediate during the acid reaction.

A second difference between the catalytic reactions of 16 and 17a with $\mathrm{PhMe} 2 \mathrm{SiH}$ is that the former reaction initially produces only the silanol $\mathrm{PhMe} 2 \mathrm{SiOH}$. Formation of disiloxane 22a appeared only after most of the starting 16 had transformed into intermediate 17 a or product $18 a .72$

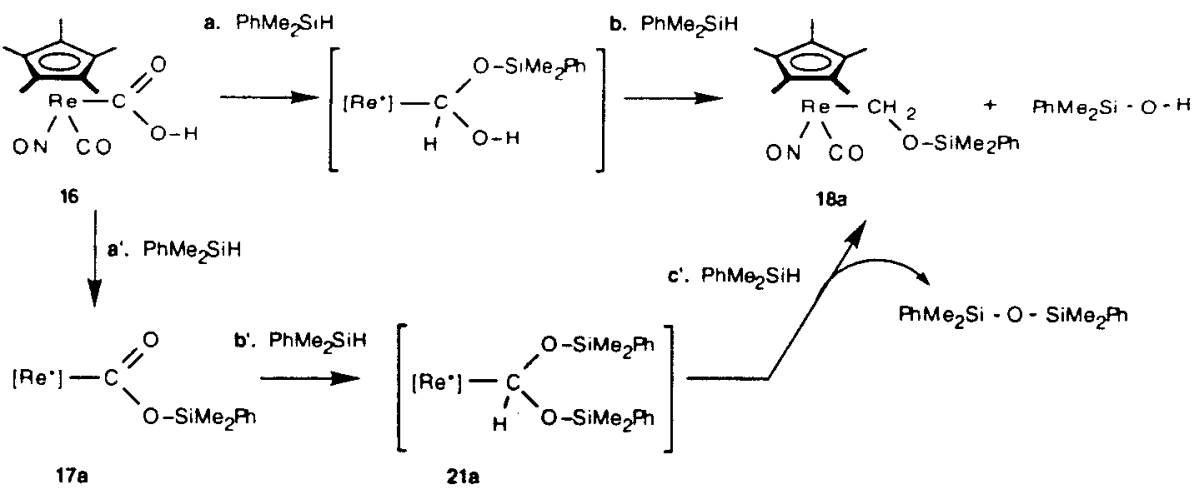

The $(\mathrm{CO})_{5} \mathrm{Mnl}(20)$-catalyzed $\mathrm{PhMe}_{2} \mathrm{SiH}$ reactions with the rhenium acid 16 comprises two parallel hemisilylacetal $(55 \%)$ and disilylacetal (45\%) pathways. According to the former (steps ab), starting 16 gives a hemisilylacetal intermediate 23a, which selectively releases silanol upon catalytic deoxygenation to 18 a (total of 2 equiv. of $\mathrm{PhMe} 2 \mathrm{SiH}$ consumed). The latter pathway (steps $\left.a^{\prime}-c^{\prime}\right)$ entails catalytic dehydrogenative silation of $\mathbf{1 6}$ followed by hydrosilation to generate a disilylacetal 21a, which subsequently releases disiloxane ( 3 equiv. of $\mathrm{PhMe} 2 \mathrm{SiH}$ consumed). ${ }^{73}$

A surprising outcome of this work was that the 20-catalyzed hydrosilation-then-reduction of 
the rhenium acid 16 and its silyl ester 17 differ from related reactions involving organic carboxylic acids and their silyl esters, e.g., $\mathrm{CH}_{3} \mathrm{CO}_{2} \mathrm{SiR}_{3}{ }^{26}$ In contrast, disilylacetals, e.g., $\mathrm{CH}_{3} \mathrm{CH}\left(\mathrm{OSiR}_{3}\right)_{2}$, are isolable, and there is no indication of a corresponding hemisilylacetal pathway with organic acids.

\section{G. Postscript.}

Finally, I must acknowledge an area of potential overlap of this last portion of my DOEsponsored research and that supported by NSF. Our NSF work is concerned with heterobimetallic $\mathrm{CO}_{2}$ complexes that have been designed to potentially facilitate (catalytic) reduction - using hydrosilanes as well as $\mathrm{H}_{2}$ - of the ligated $\mathrm{CO}_{2}$. Recent efforts have been directed towards a family of $\mathrm{Fe}_{2} \mathrm{Rh}_{2}$ and $\mathrm{Re}_{2} \mathrm{Rh} 2$ bis-carboxylates that have been designed with catalytically active $\mathrm{Rh}(\mathrm{l})$ centers appended to the $\mathrm{CO}_{2} \cdot{ }^{74}$ Much of the exploratory work has centered on the first two $\mathrm{Re}_{2} \mathrm{Rh}_{2}$ bis- $\mathrm{CO}_{2}$ adducts illustrated; their reactions with hydrosilanes thus far release the silyl esters, e.g., 17.

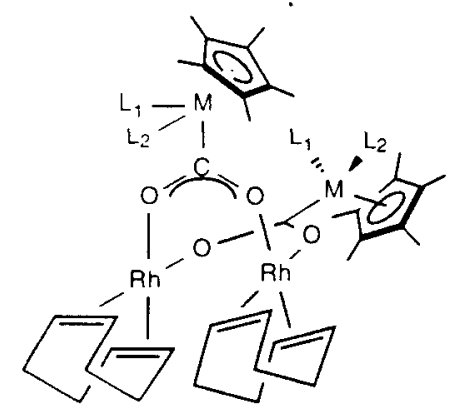

$$
\begin{aligned}
& M=R e: L_{1} \cdot L_{2}=N O, P P h_{3} ; C p \\
& M=R e ; L_{1}, L_{2}=N O, C O ; C p^{*} \\
& M=R e ; L_{1} \cdot L_{2}=N O, C O ; C p \\
& M=F e ; L_{1} \cdot L_{2}=C O ; C p^{*} \\
& M=R u: L_{1} \cdot L_{2}=C O ; C p^{*}
\end{aligned}
$$

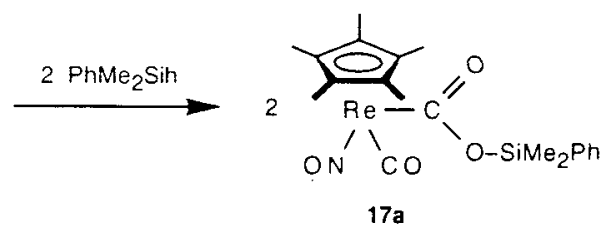

We credit the initial synthesis and characterization of rhenium silyl esters to NSF; their catalytic hydrosilation, including current and projected mechanism studies to DOE; the details of reacting hydrosilanes with $\mathrm{FeRh}$ and $\mathrm{ReRh} \mathrm{CO}_{2}$ compounds to NSF; and development and testing of $\mathrm{Mn}$ and other hydrosilation catalysts to DOE. This partial overlap of DOE and NSF research programs was temporary. NSF-sponsored research now emphasizes new types of bimetallic $\mathrm{CO}_{2}$ complexes $\left(L_{x} M\right.$ $\left.\mathrm{CO}_{2}-\mathrm{M}^{\prime} L^{\prime} x\right)_{y}$ in which the labile or catalytically active metal moiety $L_{x} M$ [e.g., $R h^{\prime}(C O)\left(P R_{3}\right) 2, \mid r^{\prime}$, and $\mathrm{Ru}^{\prime \prime}$ analogs] resides on the carbon-end $\left(\eta^{1}-\mathrm{C}\right)$ of the $\mathrm{CO}_{2}$ complex. 


\section{PUBLICATIONS}

Appearing During Grant Period (5/1/95 - 4/30/99) and Acknowledging DOE Support.

(Those in itallics acknowledge NSF support.)

1. "The Catalytic Hydrosilation of Organic Esters Using Manganese Carbonyl Acetyl Complexes,

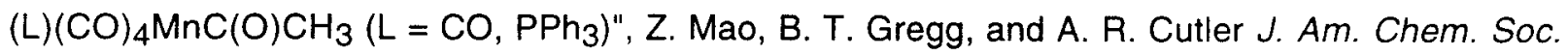
$1995,117,10139$.

2. "Hydrosilation of Manganese Acetyl $(\mathrm{CO})_{5} \mathrm{MnC}(\mathrm{O}) \mathrm{CH}_{3}$ With Monohydrosilanes", B. T. Gregg and A. R. Cutler J. Am. Chem. Soc. 1996, 118, 10069.

3. Manganese Carbonyl Complexes as Catalysts for the Hydrosilation of Ketones, A Comparison with RhCl(PPh $\left.)_{3}\right)^{\prime \prime}$, M. DiBiase, B. T. Gregg, and A. R. Cutler. Organometallics 1996, 15, 2764.

4. "Carbon Dioxide Complexation: Infrared Spectroscopy of Iron and Ruthenium $\eta^{5}$. Cyclopentadieny(carbonyl) Metallocarboxylates," J. R. Pinkes, C. J. Masi, R. Chiulli, B. D. Steffey, and A. R. Cutler, Inorg. Chem. 1997, 36, 70.

5. "Preparation and Characterization of the Rhenium Silyl Esters $\left(\eta^{5}-\mathrm{C}_{5} \mathrm{Me}_{5}\right)(\mathrm{CO})(\mathrm{NO})$ $\mathrm{ReC}(\mathrm{O}) \mathrm{OSiR}_{3}\left(\mathrm{SiR}_{3}=\mathrm{SiMe}_{2} \mathrm{Ph}, \mathrm{SiEt}_{3}\right), "$ M. DiBiase-Cavanaugh, S. M. Tetrick, C. J. Masi, and A. R. Cutler, J. Organomet. Chem. 1997, 538, 41.

6. "Re $2 R h_{2} \mu_{3}-\left[\eta^{1}-C(R e): \eta^{1}-O(R h): \eta^{1}-O^{\prime}\left(R h^{\prime}\right)\right]$ Bis-Carbon Dioxide Complexes $\left[\left(\eta^{5}-C_{5} R_{5}\right)(L)\right.$ (NO) $\mathrm{Re}\left(\mathrm{CO}_{2}\right) R h\left(\eta^{4} \text {-diene) }\right]_{2}$ that are Structurally Related to Rhodium(l) Carboxylate Dimers $\left[\mathrm{Rh}\left(\mathrm{O}_{2} \mathrm{CR}\right)\left(\eta^{4} \text {-diene }\right]_{2}\right.$," S. M. Tetrick, F. S. Tham, and A. R. Cutler, J. Am. Chem. Soc. 1997, $119,6193$.

7. "The Reactions of Hydrosilanes with the Methoxycarbonyl Complexes $\mathrm{Cp}(\mathrm{L})(\mathrm{CO}) \mathrm{MCO}_{2} \mathrm{Me}(\mathrm{M}=\mathrm{Fe}$, $\left.R u ; L=C O, P P h_{3}\right)$ and $(L)(C O)_{x} M_{C O} M e\left(M=C o, M n ; L=C O, P P h_{3} ; x=3,4\right)$, With and Without Catalysis," B. T. Gregg, M. DiBiase-Cavanaugh, R. J. Chiulli, and A. R. Cutler, J. Organomet. Chem. 1997, 547, 173.

8. "Manganese- and Rhodium- Catalyzed Phenylsilane Hydrosilation - Reduction of Iron Acyl Complexes $\mathrm{Cp}(\mathrm{L})(\mathrm{CO}) \mathrm{FeC}(\mathrm{O}) \mathrm{R}\left(\mathrm{L}=\mathrm{CO}, \mathrm{PPh}_{3}, \mathrm{PEt}_{3}, \mathrm{P}(\mathrm{OMe})_{3}, \mathrm{P}(\mathrm{OPh})_{3} ; \mathrm{R}=\mathrm{CH}_{3}, \mathrm{Ph}, \mathrm{CMe}_{3}\right)^{\prime}$, Z. Mao, B. T. Gregg, and A. R. Cutler, Organometallics 1998, 17, 1993.

9. "An Unusual Degradation of a Rhenium Silyl Ester $\mathrm{Cp}(\mathrm{NO})\left(\mathrm{PPh}_{3}\right) \mathrm{ReCO}_{2} \mathrm{SiMe}_{2} \mathrm{Ph}$ to a Bimetallic $\mu-\left[\eta^{1}-C(R e): \eta^{1}-O, O^{\prime}(R e)\right]$ Carbon Dioxide Complex $\mathrm{Cp}(\mathrm{NO})\left(\mathrm{PPh}_{3}\right) \mathrm{ReCO}_{2}$ $\operatorname{Re}(\mathrm{NO})(\mathrm{CO})\left(\mathrm{PPh}_{3}\right) \mathrm{OSiMe}_{2} \mathrm{Ph}, "$ S. M. Tetrick, M. DiBiase-Cavanaugh, F. S. Tham, and A. R. Cutler, Organometallics 1998, 17, 1925.

10. "Synthesis of $\mathrm{M}_{2} \mathrm{Rh}_{2}$ Bis- $\mu_{3}$-Carbon Dioxide Complexes from the Reaction between $\left[\mathrm{Rh}(\mathrm{OH})\left(\eta^{4}\right.\right.$ COD) $]_{2}$ and Cationic Metal Carbony/s," S. M. Tetrick, C.-Fu Xu, J. R. Pinkes, and A. R. Cutler, Organometallics 1998, 17, 1861.

11. "Characterization of the $\mu-\left(\eta^{1}-C: \eta^{2}-S, S^{\prime}\right)$ Dithiocarboxylate Complexes $C p(C O)_{2} F e C S_{2}$ $\operatorname{Zr}(X) C p_{2}\left(X=C l, \mathrm{OCMe}_{3}\right) ; \mathrm{CS}_{2}$ Insertion into the FeZr Bond of the Heterobimetallic Complex $\mathrm{Cp}(\mathrm{CO})_{2} \mathrm{Fe}-\mathrm{Zr}\left(\mathrm{OCMe}_{3}\right) \mathrm{Cp}_{2}$," J. R. Pinkes, S. M. Tetrick, B. E. Landrum, and A. R. Cutler, J. Organomet. Chem. 1998, 566, 1 . 
12. "The Reactivity the Metallocarboxylates $\mathrm{Cp}(\mathrm{NO})\left(\mathrm{PPh}_{3}\right) \mathrm{ReCO}_{2} \mathrm{M}^{+}$Towards Excess Carbon Dioxide: Degradation to a Bimetallic $\mu-\left[\eta^{1}-C(R e): \eta^{1}-O, O^{\prime}(R e)\right]$ Carbon Dioxide Complex $\mathrm{Cp}(\mathrm{NO})\left(\mathrm{PPh}_{3}\right) \operatorname{ReC\mathrm {O}_{2}} \mathrm{Re}(\mathrm{NO})(\mathrm{CO})\left(\mathrm{PPh} \mathrm{H}_{3}\right)\left(\eta^{1}-\mathrm{C}_{5} \mathrm{H}_{5}\right)$," S. M. Tetrick and A. R. Cutler,

Organometallics, 1998, manuscript accepted for publication.

13. "The Catalytic Hydrosilation and Further Reduction of Some Rhenium Silyl Esters, $\mathrm{Cp}^{*}(\mathrm{CO})(\mathrm{NO}) \mathrm{ReCO}_{2} \mathrm{R}, \mathrm{R}=\mathrm{SiMe}_{2} \mathrm{Ph}, \mathrm{SiEt}_{3}{ }^{\prime}, \mathrm{M}$. DiBiase-Cavanaugh and A. R. Cutler, J. Am. Chem.

Soc. 1998 , submitted for publication.

14. "(CO) ${ }_{5} \mathrm{Mnl}$-Catalyzed $\mathrm{PhMe}_{2} \mathrm{SiH}$ Hydrosilation and Deoxygenation of the Rhenium Carboxylic Acid, $\mathrm{Cp}^{*}(\mathrm{CO})(\mathrm{NO}) \mathrm{ReCO}_{2} \mathrm{H}$; The Case for the Hemisilylacetal Pathway", M. DiBiase-Cavanaugh and A. R. Cutler, Organometallics 1998, submitted for publication.

15. "Transformation of Manganese Acyls $(\mathrm{CO})_{5} \mathrm{MnC}(\mathrm{O}) \mathrm{CH}_{2} \mathrm{R}\left(\mathrm{R}=\mathrm{H}, \mathrm{CH}_{3}, \mathrm{OCH}_{3}\right)$ into their Siloxyvinyl Derivatives $(\mathrm{CO})_{5} \mathrm{MnC}\left(\mathrm{OSiEt}_{3}\right)=\mathrm{CHR}$ with Triethylsilane; An approach to Double Carbonylation of Manganese Alkyl Complexes $(\mathrm{CO})_{5} \mathrm{MnCH}_{2} \mathrm{R}^{\prime \prime}, \mathrm{B}$. T. Gregg and A. R. Cutler, Organometallics 1998, 17, 4169.

16. "Reactions of $\mathrm{PhMe} 2 \mathrm{SiH}$ with the Manganese Methyl Complex $(\mathrm{CO})_{5} \mathrm{MnC}(\mathrm{O}) \mathrm{CH}_{3}$ : New Reactions and a New Precatalyst, the Silylmanganese $\left(\eta^{2}-\mathrm{Si}-\mathrm{H}\right)$ Silane Adduct $(\mathrm{CO})_{4} \mathrm{Mn}\left(\mathrm{SiMe}{ }_{2} \mathrm{Ph}\right)(\mathrm{H}$ SiMe 2 Ph)", C. Xu, S. M. Tetrick, S. Punia, and A. R. Cutler, J. Am. Chem. Soc. 1998, submitted for publication.

17. "Catalytic Hydrosilation and Deoxygenation of Ligated Carbon Dioxide on the Rhenium-Stanyl and Rhenium-Zirconocene Esters $\left(\eta^{5}-C_{5} M e_{5}\right)(C O)(N O) R e C(O) O M L_{x}\left(M L_{x}=S n M e_{3}, S n P h_{3}\right.$, $\mathrm{ZrClCp} 2$, and $\mathrm{ZrClCp}{ }^{*}$ )," M. DiBiase-Cavanaugh, C. J. Masi, and A. R. Cutler, J. Am. Chem. Soc. 1998. manuscript to be submitted.

18. "Unusually Facile Carbonylation of ( $\eta^{5}$-Indenyl)ruthenium Methyl and Methoxymethyl Complexes $\left.\left(\eta^{5}-\mathrm{C}_{9} \mathrm{H}_{7}\right)(\mathrm{CO})(\mathrm{L}) \mathrm{RuR}(\mathrm{L}=\mathrm{CO}, \mathrm{PPh})^{\prime}\right)$, R. J. Chiulli, D. L. Tarazano, M. E. Dery, and A. R. Cutler, Organometallics, manuscript to be submitted.

19. "Carbonylation-assisted Alkyl Isomerization: Carbonylation of ( $\eta^{5}$-Indenyl)Ru $\alpha$-Alkoxyethyl Complexes", R. J. Chiulli, D. L. Tarazano, M. E. Dery, and A. R. Cutler, Organometallics, manuscript to be submitted.

20. "Hydrosilation of the Manganese Carbonyl Aroyl Complexes (CO) $)_{5} \mathrm{MnC}(\mathrm{O})-\mathrm{p}-\mathrm{C}_{6} \mathrm{H}_{4} \mathrm{Y}[\mathrm{Y}=\mathrm{H}, \mathrm{Me}$, 'Bu, OMe, $\left.\mathrm{CF}_{3}\right]$ ", C. Xu, B. T. Gregg and A. R. Cutler, manuscript in preparation.

21. "Preparation and Characterization of $\left(\mathrm{PPh}_{3}\right)(\mathrm{CO})_{4} \mathrm{MnSiMe} \mathrm{P}_{2} \mathrm{Ph}, \mathrm{C}$. Xu, B. T. Gregg, M. DiBiaseCavanaugh, and A. R. Cutler, manuscript in preparation. 


\section{REFERENCES and NOTES}

1. (a) Cutler, A. R.; Hanna, P. K.; Vites, J. C. Chem. Rev. 1988, 88, 1363.

2. (a) Frohning, C. D.; Kohlpaintner, Ch. W. In Applied Homogeneous Catalysis with Organometallic Compounds, Cornils, B.; Herrmann, W. A., Eds.; VCH Publishers: New York, 1996; Vol. 1, Chap. 2.1.1, p. 29. (b) Cornils, B. In New Syntheses with Carbon Monoxide, Falbe, J., Ed.; VCH Publishers: New York, 1980; Chap. 1.

3. (a) recent work: Sisak, A; Marko, L.; Angyalossy, Ungvary, F. Inorg. Chim. Acta 1994, 222, 131. (b) Keim, W. Catalysis in $C_{1}$ Chemistry, D. Reidel Publishers: Boston, 1983.

4. Reviews on ketone hydrosilation: (a) Ojima, I. In The Chemistry of Organic Silicon Compounds; Patai, S.; Rappoport, Z., Eds.; Wiley: New York, 1989; Chapter 25. (b) Chaloner, P. A. Handbook of Coordination Catalysis in Organic Chemistry, Butterworths: Boston, 1986; Chapter 7.2. (c) Marciniec, B.; Guliñski, J. J. Organomet. Chem. 1993, 446, 15.

5. Harada, K.; Munegumi, T. In Comprehensive Organic Synthesis, Trost, B . M.; Fleming, I., Eds.; Pergamon Press: New York, 1991; Vol. 8, Chap. 1.6, p. 149.

6. $D\left(\mathrm{Me}_{3} \mathrm{Si}-\mathrm{H}\right), 93 \mathrm{kcal} / \mathrm{mol}^{6}$ d,e $D\left(\mathrm{Me}_{3} \mathrm{Si}-\mathrm{O}-\mathrm{SiMe}_{3}, 253 ; 6 \mathrm{C} D\left(\mathrm{Me}_{3} \mathrm{Si}-\mathrm{OH}, 128 ; \quad D\left(\mathrm{Me}_{3} \mathrm{SiO}-\mathrm{H}\right.\right.\right.$, 118; $D\left(\mathrm{Me}_{3} \mathrm{Si}-\mathrm{OMe}, 114{ }^{6 a, b}\right.$ (a) Pilcher, G.; Leitao, M. L. P.; Meng-Yan, Y.; Walsh, R. J. Chem. Soc., Faraday Trans. 1991, 87, 841. (b) Marshall, P.; Ding, L. J. Amer. Chem. Soc. 1992, 114, 5754. (c) Luo, L.;; Lanza, G.; Fragala, I. L.; Stern, C. L.; Marks, T. J. J. Amer. Chem. Soc. 1998, 120, 3111. (d) Walsh, R. In The Chemistry of Organic Silicon Compounds; Patai, S.; Rappoport, Z., Eds.; Wiley Interscience: New York, 1989; Part 1, Chapter 5. (e) Walsh, R. Acc. Chem. Res. 1981, 14, 246.

7. In this discussion, silanes refer to hydrosilanes with at least one $\mathrm{Si}-\mathrm{H}$, and alkoxysilanes may retain a Si-H depending on the starting silane that was added to a carbonyl group. Labile alkyl complexes exchange coordinated $\mathrm{CO}$ ligands and also undergo alkyl-CO insertion reactions (i.e., carbonylation) under mild conditions. ${ }^{8}$ In terms of reaction temperatures for analogous reactions, lability of ther isolobal organometallic systems decreases: $-\mathrm{Co}(\mathrm{CO})_{4}>-$ $\mathrm{Co}\left(\mathrm{PR}_{3}\right)(\mathrm{CO})_{3}>-\mathrm{Mn}(\mathrm{CO})_{5}>-\mathrm{Mn}\left(\mathrm{PR}_{3}\right)(\mathrm{CO})_{4}>-\mathrm{Fe}(\mathrm{CO})(\mathrm{L}) \mathrm{Cp}$.

8 Labile with respect to reversible carbonyl ligand dissociation for 1: (a) Noack, K.; Calderazzo, F. J. Organomet. Chem. 1967, 10, 101. (b) Flood, T. C.; Jensen, J. E.; Statler, J. A. J. Amer. Chem. Soc. 1981, 103, 4411. (c) Boese, W. T.; Lee, B.; Ryba, D. W.; Belt, S. T.; Ford, P. C. Organometallics 1993,12, 4739, and references cited.

9. (a) Wegman, R. W. Organometallics 1986, 5, 707. (b) Reviews on the reactivity of metal silyl complexes: Tilley, T. D. In The Chemistry of Organic Silicon Compounds; Patai, S.; Rappoport, Z., Eds.; Wiley Interscience: New York, 1989; Part 2, Chapter 24. Tilley, T. D. In The SiliconHeteroatom Bond ; Patai, S.; Rappoport, Z., Eds.; Wiley: New York, 1992; Chapter 10. (c) Braunstein, P.; Knorr, M. J. Organomet. Chem. 1995, 500, 21.

10. (a) Seki, Y.; Kawamoto, K.; Chatani, N.; Hidaka, A.; Sonoda, N.; Ohe, K.; Kawasaki, Y.; Murai, S. J. Organomet. Chem. 1991, 403, 73, and references cited. (b) Catalyzed silylformylation of aldehydes with $(\mathrm{CO})_{4} \mathrm{CoSiR}_{3}{ }^{10 \mathrm{C}}$ and with $\mathrm{Rh}(\mathrm{I})$ complexes ${ }^{10 \mathrm{~d}}$ probably involves a similar 
pathway involving $\alpha$-siloxyalkyl intermediates, $L_{x} M C H\left(\mathrm{OSiR}_{3}\right) R^{\prime}$. (c) Chatani, N.; Fugii, $S_{\text {.; }}$ Yamasaki, Y.; Murai, S.; Sonoda, N. J. Amer. Chem. Soc. 1986, 108, 7361. Murai, T.; Yasui, E.; Kato, S.; Hatayama, Y.; Suzuki, S.; Yamasaki, Y.; Sonoda, N.; Kurosawa, H.; Kawasaki, Y.; Murai, S. J. Am. Chem. Soc. 1989, 111, 7938. Kreisz, J.; Sisak, A.; Markó, L.; Ungváry, F. J. Organomet. Chem. 1993, 451, 53. Chatani, N.; Tokuhisa, H.; Kokubu, I.; Satoru, F.; Murai, S. J. Organomet. Chem. 1995, 499, 193. (d) Wright, M. E.; Cochran, B. B. Organometallics 1996, 15, 317. Leighton, J. L.; Chapman, E. J. Am. Chem. Soc. 1997, 119, 12416, and references cited.

11. (a) Gladysz, J. A. Acc. Chem. Res. 1984, 17, 326. Brinkman, K. C.; Gladysz, J. A. Organometallics 1984, 3, 147. (b) Stable (CO) ${ }_{5} \mathrm{ReCH}\left(\mathrm{OSiMe}_{3}\right) \mathrm{Ph}$ and several chelated $\mathrm{Mn}$ and Re analogs had been fully characterized as reaction products of $(\mathrm{CO})_{5} \mathrm{MOSiMe}$ plus an aldehyde. Selover, J. C.; Vaughn, G. D.; Strouse, C. E.; Gladysz, J. A. J. Am. Chem. Soc. 1986, $108,1455$. Vaughn, G. D.; Strouse, C. E.; Gladysz, J. A. J. Am. Chem. Soc. 1986, 108, 1462. Vaughn, G. D.; Gladysz, J. A. J. Am. Chem. Soc. 1986, 108, 1473.

12. Kovacs, I.; Sisak, A.; Ungváry, F.; Markó, L. Organometallics 1988, 7, 1025.

13. Hanna, P. K.; Gregg, B. T.; Tarazano, D. L.; Pinkes, J. R.; Cutler, A. R. In Homogeneous Transition Metal Catalyzed Reactions; Advances in Chemistry 230; 1992, p. 491.

14. (a) Crawford, E. J.; Hanna, P. K.; Cutler, A. R. J. Am. Chem. Soc. 1989, 111, 6891. (b) Mao, Z.; Gregg, B. T.; Cutler, A. R. Organometallics 1998, $17,1993$. (c) Pinkes, J. R.; Mao, Z.; Cutler, A. R., manuscript in preparation.

15. (a) Hanna, P. K.; Gregg, B. T.; Cutler, A. R. Organometallics 1991, 10, 31. (b) Gregg, B. T.; Cutler, A. R. J. Am. Chem. Soc. 1996, 118, 10069. (c) Gregg, B. T.; Cutler, A. R. Organometallics 1999, accepted for publication.

16. (a) Gregg. B. T.; Hanna, P. K.; Crawford, E. J.; Cutler, A. R. J. Am. Chem. Soc. 1991, 113, 384. (b) Mao, Z.; Gregg, B. T.; Cutler, A. R. Organometallics 1998, 17, 1993.

17. The reactivity order of the hydrosilanes, $\mathrm{RSiH}_{3} \gg \mathrm{R}_{2} \mathrm{SiH}_{2}>\mathrm{R}_{3} \mathrm{SiH}$, has been established for the $\mathrm{Rh}\left(\mathrm{PPh}_{3}\right)_{3} \mathrm{Cl}$-catalyzed hydrosilation of ketones. ${ }^{4}$

18. This mechanism resembles those advanced for the hydrosilation/reduction of the acyl ligand on $\mathrm{Cp}(\mathrm{L})(\mathrm{CO}) \mathrm{FeC}(\mathrm{O}) \mathrm{CH}_{2} \mathrm{CH}_{2} \mathrm{Ph}$. (a) Akita, M.; Oku, T.; Moro-oka, Y. J. Chem. Soc., Chem.

Commun. 1989, 1790. Akita, M.; Oku, T.; Tanaka, M.; Moro-oka, Y. Organometallics 1991, 10, 3080. (b) Brunner, H.; Fisch, K. Ang. Chem., Int. Ed. Engl. 1990, 29, 1131; J.

Organomet. Chem. 1991, 412, C11.

19. Gregg, B. T.; Cutler, A. R. Organometallics 1992, 11, 4276.

20. (a) Akita, M.; Mitani, O.; Moro-Oka, Y. J. Chem. Soc., Chem. Commun. 1989, 527. (b) Akita, M.; Mitani, O.; Sayama, M.; Moro-Oka, Y. Organometallics 1991, 10, 1394.

21. (a) Akita, M.; Hua, R.; Nakanishi, S.; Tanaka, M.; Moro-oka, Y. Organometallics 1997, 16, 5572. (b) Akita, M.; Hua, R.; Oku, T.; Tanaka, M.; Moro-oka, Y. Organometallics 1996, 15, 4162. (c) Akita, M.; Hua, R.; Oku, T.; Moro-oka, Y. Organometallics 1996, 15, 2548 . (d) 
Akita, M.; Noda, K.; Takahashi, Y.; Moro-oka, Y. Organometallics 1995, 14, 5209.

22. (a) Chatani, N.; Shinohara, M.; Iketa, S.; Murai, S. J. Amer. Chem. Soc. 1997, 119, 4303, and references cited. (b) Chatani, N.; Murai, S. Synlett. 1996, 414. (c) Handwerker, H.; Beruda, H.; Kleine, M.; Zybill, C. Organometallics 1992, 11, 3542.

23. (a) Treichel, P. M. In Comprehensive Organometallic Chemistry; Wilkinson, G.; Stone, F. G. A., Eds.; Pergamon Press: Oxford, U. K. 1982; Vol. 4, Chapter 29. Casey, C. P. In Comprehensive Organometallic Chemistry II; 1996; Vol.6, Chap. 1.

24. DiBiase-Cavanaugh, M.; Gregg, B. T.; Cutler, A. R. Organometallics 1996, 15, 2764.

25. Gregg, B. T.; Cutler, A. R. Organometallics 1994, 13, 1039.

26. Mao, Z.; Xu, C.F.; Cutler, A. R. manuscript submitted.

27. Mao, Z.; Gregg, B. T.; Cutler, A. R. J. Am. Chem. Soc. 1995, 117, 10139.

28. (a) Gregg, B. T.; Cutler, A. R. Organometallics 1993, 12, 2006. (b) Xu, C. F.; Gregg, B. T. ; Cutler, A. R., manuscript in preparation. Also ref. 15a.

29. DiBiase-Cavanaugh, M.; Cutler, A. R. Organometallics, manuscript in preparation.

30. DiBiase-Cavanaugh, M.; Gregg, B. T.; Chiulli, R. J.; Cutler, A. R., J. Organomet. Chem. 1997, $547,173$.

31. DiBiase-Cavanaugh, M.; Cutler, A. R. J. Am. Chem. Soc., manuscript submitted.

32. (a) Xu, C. F.; Tetrick, S. M.; Punia, S.; Cutler, A. R. J. Am. Chem. Soc., manuscript submitted.

(b) work in progress. (c) Mao, Z; Xu, C. F.; Cutler, A. R., manuscript in preparation. (d) Xu, C. F.; Cutler, A. R., unpublished observations.

33. Coordinatively unsaturated (or weakly ligated) metal carbonyl silyl complexes that are isolobal with $(\mathrm{CO})_{4} \mathrm{MnSiR}_{3}$ have been generated thermally $\left[\mathrm{CpFe}(\mathrm{CO}) \mathrm{SiR}_{3}\right]^{18 a, b}$ and photochemically $\left[(\mathrm{CO})_{3} \mathrm{CoSiR}_{3},{ }^{33 \mathrm{a}, \mathrm{b}} \mathrm{CpFe}(\mathrm{CO}) \mathrm{SiR}_{3} / \mathrm{CpFe}(\mathrm{CO}) \mathrm{SnR}_{3}, 33 \mathrm{c}, \mathrm{d}(\mathrm{CO})_{4} \mathrm{MnSiR}_{3} /(\mathrm{CO})_{4} \mathrm{MnSnR}_{3}{ }^{33 e}\right]$. (a) Reichel, C. L.; Wrighton, M. S. Inorg. Chem. 1980, 19, 3858. Anderson, F. R.; Wrighton, M. S. J. Am. Chem. Soc. 1984, 106, 995. (b) Wrighton, M. S.; Seitz, M. S. Ang. Chem., Int. Ed. Engl. 1988, 27, 289. (c) Randolph, C. L.; Wrighton, M. S. J. Am. Chem. Soc. 1986, 108, 3366.

(d) Zhang. S.; Brown, T. L. Organometallics 1992, 11, 2122. Kawano, Y.; Tobita, H.; Ogino, H. J. Organomet. Chem. 1992, 428, 125. Haynes, A.; George, M. W.; Haward, M. T.; Poliakoff, M.; Turner, J. J.; Boag, N. M.; Green, M. J. Am. Chem. Soc. 1991, 113, 2011, and refernces therein. (e) Sullivan, R. J.; Brown, T. L. J. Am. Chem. Soc. 1991, 113, 9155.

34. Isolobal examples of (hydrido)(silyl)(alkyl)Colll,33d,34a (hydrido)(silyl) 2 Colll,33c (hydrido)(silyl) ${ }_{2} \mathrm{Fe}(\mathrm{CO}) \mathrm{Cp},{ }^{33 a, b, e}\left[(\mathrm{CO})_{5} \mathrm{Mn}\right](\mathrm{CO})_{4} \mathrm{MnH}(\mathrm{SnBu} 3)$, and $(\mathrm{CO})_{4} \mathrm{MnH}(\mathrm{SnBu})_{2}{ }^{33 \mathrm{~g}}$ species have been characterized as the products of similar oxidative-addition / reductiveelimination sequences. Other examples of (hydrido)(silyl)(alkyl)metal complexes have been reported or implicated as intermediates in hydrosilation catalysis. ${ }^{34 \mathrm{~b}}$ (a) Hardin, S.; Turney, T. W. J. Mol. Cat. 1987, 39, 237. Archer, N. J.; Haszeldine, R. N.; Parish, R. V. J. Chem. Soc., Dalton Trans. 1979, 695. (b) Campion, B. K.; Heyn, R. H.; Tilley, T. D.; Rheingold, A. L. J. Am. Chem. Soc. 1993, 115, 5527, and references therein.

35. Schubert, U. Adv. Organomet. Chem. 1990, 30, 151. 
36. (a) Misumi, Y.; Ishii, Y.; Hidai, M. Organometallics 1995, 14, 1770. (b) Johnson, D. L.; Glagysz, J. A. Inorg. Chem. 1981, 20, 2508.

37. (a) Dombek, B. D. J. Am. Chem. Soc. 1979, 101, 6466.

38. (a) Halpern, J. Acc. Chem. Res. 1982, 15, 332. Webb, S. L.; Giandomenico, C. M.; Halpern, J. J. Am. Chem. Soc. 1986, 108, 345. (b) Warner, K. E.; Norton, J. R. Organometallics 1985, 4, 2150. Martin, B. D.; Warner, K. E.; Norton, J. R. J. Am. Chem. Soc. 1986, 108, 33. (c) Bullock, R. M.; Rappoli, B. J. J. Am. Chem. Soc. 1991, 113, 1659, and references cited. (d) Anderson, J. M.; Moss, J. R. Adv. Organomet. Chem. 1995, 37, 169.

39. Johnson, B. F. G.; Johnston, R. D.; Lewis, J.; Robinson, B. H. Inorg. Synth. 1970, $12,43$. Kirtley, S. W.; Olsen, J. P.; Bau, R. J. Am. Chem. Soc. 1973, 95, 4532.

40. The production of the ethoxysilane 11, although engendering different chemistry than that exhibited by the acetyl $1,15 \mathrm{~b}$ is the expected result of alkyl-CO migration then intramolecular hydrosilation. These same coupled reactions occur during the catalytic siloxymethylation of a variety of substrates. For example, Akita and Moro-oka18a reported that heating $\mathrm{FpCH}_{2} \mathrm{CH}_{2} \mathrm{Ph}$ and excess of $\mathrm{Ph}_{2} \mathrm{SiH}_{2}$ at $120^{\circ} \mathrm{C}$ formed the disilylhydride complex $\mathrm{Cp}(\mathrm{CO}) \mathrm{FeH}\left(\mathrm{SiHPh}_{2}\right)_{2}{ }^{18 \mathrm{~b}}$ plus $\mathrm{Ph}\left(\mathrm{CH}_{2}\right)_{3} \mathrm{OSiHPh}_{2}$.

41. (a) Aizenberg, M.; Milstein, D. J. Am. Chem. Soc. 1995, 117, 6456. (b) Lin, W.; Wilson, W. R.; Girolami, G. S. Organometallics 1994, 13, 2309.

42. This step resembles that proposed for our catalytic deoxygenation of organic esters, 27 silyl esters, 26 and metal acyl complexes. ${ }^{16 b}$

43. Similarly detailed studies also have been carried out on the reactions of $\mathrm{PhMe}_{2} \mathrm{SiH}$ with $\left(\mathrm{PPh}_{3}\right)(\mathrm{CO})_{4} \mathrm{MnCH}_{3},(\mathrm{~L})(\mathrm{CO})_{4} \mathrm{MnCH}_{2} \mathrm{Ph}\left(\mathrm{L}=\mathrm{CO}, \mathrm{PPh}_{3}\right),(\mathrm{L})(\mathrm{CO})_{4} \mathrm{Mn}-\mathrm{p}-\mathrm{C}_{6} \mathrm{H}_{4} \mathrm{Y}$, and (L) $(\mathrm{CO})_{4} \mathrm{MnH}$. $32 \mathrm{~d}$ Our standard procedure included: (1) doing reactions at room temperature and at $40^{\circ} \mathrm{C}$ in $\mathrm{C}_{6} \mathrm{D}_{6}$ in the presence of 2 and 4 equiv. of $\mathrm{PhMe} 2 \mathrm{SiH}$ (and if warranted, $\mathrm{Ph}_{2} \mathrm{SiH}_{2}$ and $\mathrm{PhSiH}_{3}$ ), (2) monitoring by ${ }^{1} \mathrm{H},{ }^{13} \mathrm{C},{ }^{29} \mathrm{Si}$, and ${ }^{31} \mathrm{P}$ NMR spectroscopy, (3) repeating selected reactions in the presence of $\mathrm{H}_{2}, \mathrm{CO}$, and $\mathrm{PPh}_{3},(4)$ surveying selected reactions as precatalyst sources for (a) hydrosilation of acetone with $\mathrm{PhMe}_{2} \mathrm{SiH}$, (b) hydrosilationdeoxygenation of ethyl acetate with 3 equiv. of $\mathrm{PhMe}_{2} \mathrm{SiH}$ or $\mathrm{Ph}_{2} \mathrm{SiH}_{2}$, and (c) dehydrogenative silation-hydrosilation-deoxygenation of acetic acid with 3 equiv. of $\mathrm{PhMe}_{2} \mathrm{SiH}$ or $\mathrm{Ph}_{2} \mathrm{SiH}_{2}$. Only the benzyl complexes afforded truly useful hydrosilane chemistry.

44. These runs entailed adding an aliquot from a preparation of 4 to the substrate and an excess of the new hydrosilane. We are of course cognizant of the pitfalls of doing catalysis with a mixture of several components, of which one is alleged to function as the precatalyst. All other detectable components individually are ineffective catalysts: Other sources of 4 (which realize different byproducts) - including $(\mathrm{CO})_{5} \mathrm{MnC}(\mathrm{O}) \mathrm{Ph}(2)$ and $(\mathrm{CO})_{5} \mathrm{MnSiR}_{3}(\mathrm{hv})$ - effect the same product distributions during silane catalysis runs. The proposal section deals with generating and characterizing stabilized but still reactive analogs of 4 .

45. (a) Ojima, I.; Donovan, R. J.; Clos, N. Organometallics 1991, 10, 2606, and references cited.

46. Van Doorn, J. A.; Masters, C.; Volger, H. C. J. Organomet. Chem. 1983, 243, 87. 
47. (a) The nonconjugated ester functional group is inert in the presence of hydrosilanes (e. g., $\left.\mathrm{Ph}_{2} \mathrm{SiH}_{2}\right)$ and $\mathrm{Rh}\left(\mathrm{PPh}_{3}\right)_{3} \mathrm{Cl}$, the traditional ketone hydrosilation catalyst. ${ }^{4,45}$ Ojima, 1.;

Kumagai, M.; Nagai, Y. J. Organomet. Chem. 1976, 111, 43. Ojima, I.; Kogure, T.; Kumagai, M. J. Org. Chem. 1977, 42, 1671. (b) Rh(l)-catalyzed 1,4-hydrosilation of $\alpha$, $\beta$-unsaturated esters: Chan, T. H; Zheng, G. Z.. Tetrahedron Lett. 1993, 34, 3095; Zheng, G. Z.; Chan, T. H. Organometallics 1995, 14, 70, and references therein. (c) For intramolecular hydrosilation of $\beta$-siloxyesters, Davis, A. P.; Hegarty, S. C. , and references therein.

48. Recent examples of homogeneously catalyzed reactions of hydrosilanes with esters typically give silyl ethers or $1^{\circ}$ alcohols after workup: (a) Berk, S. C.; Kreutzer, K. A.; Buchwald, S. L. J. Amer. Chem. Soc. 1991, 113, 5093. (b) Berk, S. C.; Buchwald, S. L. J. Org. Chem. 1992, 57, 3751. (c) Barr, K. J.; Berk, S. C.; Buchwald, S. L. J. Org. Chem. 1994, 59, 4323. (d) Breeden, S. W.; Lawrence, N. J. SYNLETT 1994, 833.

49. Other examples of $\mathrm{Rh}(\mathrm{I})$-catalyzed deoxygenation of $\alpha$-siloxyalkyl ligands with hydrosilanes also have been reported, see references $14,20,26,29,31$.

50. Xu, C.F.; Mao, Z.; Cutler, A. R., to be published.

51. ${ }^{13} \mathrm{C}$ NMR spectral monitoring of these reactions was especially informative, since the central carbons of ester-derived ethers, silyl ethers, and silyl acetals exhibit distinctive spectral ranges. ${ }^{1} \mathrm{H}$ and ${ }^{13} \mathrm{C}$ NMR spectral correlations were were used to discern mono- bis-, and trissilyl ethers of $\mathrm{PhSiH}_{3}$, e.g., $\mathrm{PhSiH}_{x}\left(\mathrm{OCH}_{2} \mathrm{R}\right)_{3-\mathrm{x}}$, as well as the corresponding silyl acetals, $\mathrm{PhSiH}_{x}\left[\mathrm{OCHR}\left(\mathrm{OR}^{\prime}\right)\right]_{3-\mathrm{x}}$. Authentic samples of these $\mathrm{PhSiH}_{3}$-derived silyl ethers were generated via controlled dehydrogenative silation of the requisite alcohols and were characterized by ${ }^{1} \mathrm{H}$, ${ }^{13} \mathrm{C},{ }^{29} \mathrm{Si}$ NMR spectroscopy. Small amounts of mixed silyl acetal-silyl ether and perhaps silyl acetal-siloxane compounds are sometimes detected, but not identified.

52. Products were isolated after treating $\mathrm{HCO}_{2} \mathrm{Et}$ with 1.2 equiv. of silane and $3 \% 1$ or 7 for $5 \mathrm{hr}$. These reactions provided $65-88 \%$ yields of the silyl acetals plus $5-15 \%$ of $1: 1$ methyl and ethyl silyl ether mixtures. Fully characterized silyl acetals were isolated by flash chromatography.

53. Lahoz, F. J.; Martin, A.; Esteruelas, M. A.; Sola, E.; Serrano, J. L.; Oro, L. A. Organometallics 1991, 10, 1794.

54. (a) Jessop, P. G.; Ikariya, T.; Noyori, R. Chem. Rev. 1995, 95, 259. Jessop, P. G.; Hsiao, Y.; Ikariya, T.; Noyori, R. J. Am. Chem. Soc. 1996, 118, 344. (b) Leitner, W.; Dinjus, E.; Grassner, F. J. Organomet. Chem. 1996, 511, 145. Leitner, W. Ang. Chem. Int. Ed. Engl. 1995, 34, 2207. Hutschka, F.; Dedieu, A; Eichenberger, M.; Fornika, R.; Leitner, W. J. Am. Chem. Soc. 1997, 119, 4432. (c) Tsai, J.-C.; Nicholas, K. M. J. Am. Chem. Soc. 1992, 114, 5117. 55. (a) Leitner, W.; Dinjus, E.; Gassner, F. J. Organomet. Chem. 1994, 475, 257. (b) Gassner, F.; Dinjus, E.; Görls, H.; Leitner, W. Organometallics 1996, 15, 2078. (c) Marciniec, B.; Krzyzanowski, P. J. Organomet. Chem. 1995, 493, 261. (d) Bönnemann, H.; Brijoux, W.; Brinkman, R.; Dinjus, E.; Fretzen, R.; Joußen, T.; Korall, B. J. Mol. Cat. 1992, 74, 323.

56. (a) Werner, W.; Schäfer, M.; Nürnberg, O.; Wolf, J. Chem. Ber. 1994, 127, 27. Schneider, D.; Werner, W. Ang. Chem. Int. Ed. Engl. 1991, 30, 700. and references cited. (c) Wang, K.; 
Emge, T. J.; Goldman, A. S. Organometallics 1995, 14, 4929.

57. Birkofer, L.; Stuhl, O. In The Silicon-Heteroatom Bond; Patai, S.; Rappoport, Z., Eds.; Wiley : New York, 1992; Chapter 10.

58. $\mathrm{PhMe}_{2} \mathrm{SiH}$ and $\mathrm{EtMe}_{2} \mathrm{SiH}$ are the most effective hydrosilanes for the first two steps. Treatment of 1.2 equiv. of the carboxylic acid substrate either with $\mathrm{RMe}_{2} \mathrm{SiH}$ and $3 \% 1,7$ or $(\mathrm{CO})_{5} \mathrm{MnBr}$ precatalyst affords $84-90 \%$ silyl ester. Treatment of acetic acid, 3.2 equiv. of $\mathrm{RMe}_{2} \mathrm{SiH}$, and the precatalysts 1 or 7 yielded $90-98 \%$ of the fully characterized disilyl acetals $\mathrm{CH}_{3} \mathrm{CH}\left(\mathrm{OSiMe}_{2} \mathrm{R}\right)_{2}$ after 3 and $20 \mathrm{~h}$, respectively. The $\mathrm{PhSiH}_{x}\left(\mathrm{OCH}_{2} \mathrm{CH}_{3}\right)_{3-x}$ resulting from the 7 -catalyzed $\mathrm{PhSiH}_{3}$ reaction with $\mathrm{CH}_{3} \mathrm{CO}_{2} \mathrm{SiMe}_{2} \mathrm{Et}$ was not purfied. NMR spectral data for each of the three silyl ethers, however, is available from 7-catalyzed $\mathrm{PhSiH}_{3}$ reactions with ethanol. Treatment of $\mathrm{CH}_{3} \mathrm{CO}_{2} \mathrm{SiMe}_{2} \mathrm{Et}$ with $\mathrm{Ph}_{2} \mathrm{SiH}_{2}$ and 1 provided varying ratios of $\mathrm{Ph}_{2} \mathrm{Si}\left[\mathrm{OCH}\left(\mathrm{CH}_{3}\right) \mathrm{OSiMe}_{2} \mathrm{Et}\right]_{2}$ and $\mathrm{Ph}_{2} \mathrm{SiH}\left[\mathrm{OCH}\left(\mathrm{CH}_{3}\right) \mathrm{OSiMe}_{2} \mathrm{Et}\right.$ ) disilyl acetals (90-95\%), which were isolated and fully characterized.

59. Klinger, R. J.; Rathke, J. W. Prog. Inorg. Chem. 1991, 39, 113.

60. Herrmann, W. A. In Applied Homogeneous Catalysis with Organometallic Compounds, Cornils, B.; Herrmann, W. A., Eds.; VCH Publishers: New York, 1996; Vol. 2, Chap. 3.2.11, p. 957.

61. Reference 68 has a comprehensive listing of characterized metallocarboxylic acids.

62. (a) Angelici, R.J. Acc. Chem. Res., 1972, 5, 335; Ford, P.C.; Rokicki, A. Adv. Organomet. Chem., 1988, 28 , 139. (b) Pandey, K. K. Coord Chem. Rev. 1995, 140, 37. Jessop, P. G.; Ikariya, T.; Noyori, R. Chem. Rev. 1995, 95, 259. (c) Alkoxycarbonyl complexes that have been synthesized by alkylation of nucleophilic metal $\mathrm{CO}_{2}$ adducts: Harlow, R. L.; Kinney, J. B.; Herskovitz, T. J. Chem. Soc., Chem. Commun. 1980, 813. Ishida, H.; Tanaka, K.; Tanaka, T. Organometallics 1987, 6, 181; Nakajima, H.; Tanaka, H.; Tzeng, B. -C.; Nagao, H.; Peng. S. M.: Tanaka, K. Inorg. Chem. 1993, 32, 1508; Gibson, D. H.; Ong, T. -S.; Ye, M. Organometallics 1991, 10, 1811; Gibson, D. H.; Franco, J. O.; Harris, M. T.; Ong, M. T. Organometallics 1992, 11, 1993.

63. Thorn, D. L. Organometallics 1982, 1, 197.

64. Forschner. T.; Menard, K.; Cutler, A. J. Chem. Soc., Chem. Commun. 1984, 121.

65. (a) Casey, C. P.; Tukada, H.; Miles, W. H. Organometallics 1982, 1, 1083. (b) Löwe, C.; Huttner, G.; Zsolnai, L.; Berke, H. Z. Naturforsch. 1988, 43b, 25. (c) Guillevic, M. A.; Bregaint, P.: Lapinte, C. J. Organomet. Chem. 1996, 514, 157.

66. Reference $3 a$ and papers cited therein.

.67. Gibson, D. H.; Mehta, J. M.; Ye, M.; Richardson, J. F.; Mashuta, M. S. Organometallics 1994, 13. 1070.

68. DiBiase-Cavanaugh, M.; Tetrick, S. M.; Masi, C. J.; Cutler, A. R. J. Organomet. Chem. 1997, 538,41 .

69. Dombek, B. D. Adv. Catal. 1983, 32, 325; Organometallics 1985, 4, 1707.

70. These results underscore a greater proclivity of $\mathrm{PhMe} 2 \mathrm{SiH}$ (even when present in much lower concentrations) than $\mathrm{Et}_{3} \mathrm{SiH}$ to hydrosilate a silyl ester and deoxygenate its resulting silylacetal. 
The $\mathrm{PhMe}_{2} \mathrm{SiH}$ extruded during the silyl exchange, $17 \mathrm{a}$ to $17 \mathrm{~b}$, is consumed selectively in their hydrosilation and in subsequent deoxygenation of their disilylacetals $21 \mathrm{a}$ and $\left[\mathrm{Re}^{*}\right] \mathrm{CH}\left(\mathrm{OSiMe}_{2} \mathrm{Ph}\right)\left(\mathrm{OSiEt}_{3}\right)(21 \mathrm{ab})$. This latter reaction preferentially transforms $21 \mathrm{ab}$ to $18 \mathrm{~b}(39 \%)$ and $21 \mathrm{a}$ to $18 \mathrm{a}(12 \%)$ in order to account for the predominance of $22 \mathrm{a}$ over $22 \mathrm{ab}$. The relatively large buildup of $17 \mathrm{~b}$ in this reaction of course confirms its relatively sluggish hydrosilation reactivity towards $\mathrm{Et}_{3} \mathrm{SiH}$. Similar details for the crossover reactions involving $\mathrm{PhMe} 2 \mathrm{SiH} / 17 \mathrm{~b}$ and $\mathrm{Ph}_{2} \mathrm{SiH}_{2} / 17 \mathrm{a}$ and $17 \mathrm{~b}$ also have been delineated.

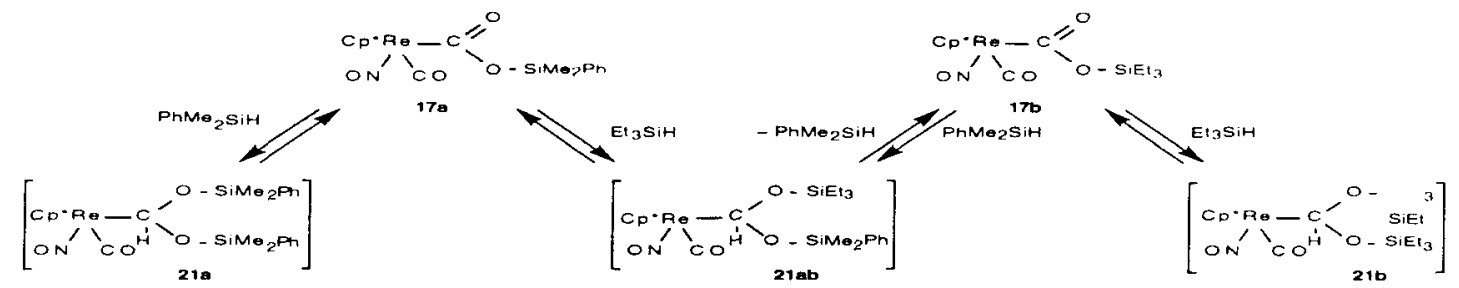

71. This study depended upon our ability to identify and quantitate unsymmetric disiloxanes, some of which were unknown. In order to collect the necessary ${ }^{1} \mathrm{H},{ }^{13} \mathrm{C},{ }^{29} \mathrm{Si}$ NMR spectral data, we selectively generated these compounds in near quantitative yields via 20-catalyzed dehydrogenative silation of a silanol $\mathrm{R}_{3} \mathrm{SiOH}$ with the requisite hydrosilane. All of the unsymmetric disiloxanes necessary to this study involving the four silyl groups mentioned were characterized.

72. Typical data gleaned from a reaction profile (time-concentration) for 20-catalyzed reaction between 16 and 2.8 equiv. of $\mathrm{PhMe}_{2} \mathrm{SiH}$ : by $100 \mathrm{~min} .,<10 \% 16$ remained; the sum of the $17 \mathrm{a}$ and $18 \mathrm{a}$ accounted for $93 \%$ of the starting 16 . After $220 \mathrm{~min}$., an $89 \%$ yield of $18 \mathrm{a}$ corresponds to 2.4 equiv. of $\mathrm{PhMe}_{2} \mathrm{SiH}$ consumed per $18 \mathrm{a}$ formed.

73. The surprisingly low reactivity of the silyl ester 17 a during the $\mathrm{PhMe} 2 \mathrm{SiH}$ reactions with the rhenium acid 16 and indeed the overall sluggishness of this reaction is due to the starting 16 inhibiting the catalytic hydrosilation and reduction of $17 \mathrm{a}$. The normally rapid reaction of $17 \mathrm{a}$ thus was suppressed while 16 slowly converted to $18 \mathrm{a}$ plus silanol. This inhibition (as well as that of the catalytic conversion of $\mathrm{PhMe} \mathrm{SiH}_{2}$ and $\mathrm{PhMe}_{2} \mathrm{SiOH}$ to 22a) was confirmed by control reactions.

74. (a) Tetrick, S. M.; Tham, F. S.; Cutler, A. R. J. Am. Chem. Soc. 1997, 119, 6193. (b) Tetrick, S. M.; Xu, C.-Fu, Pinkes, J. R.; Cutler, A. R. Organometallics 1998, 17, 1861. 


\section{TIME AND EFFORT COMMITMENT TO PROJECT}

The principal investigator has devoted approximetely $40 \%$ of his time during the academic year and $100 \%$ during two summer months on this project. It is anticipated that about the same time and effort commitment will be maintained during the remainder of the current term. 